\title{
ESTUDOS ESSAYS
}

\section{Wellington e Napoleão: Representações Britânicas e Portuguesas no Romance e no Ecrã ${ }^{1}$ (Projecto Portrayals of the Peninsular War: From The Novel to the Screen]}

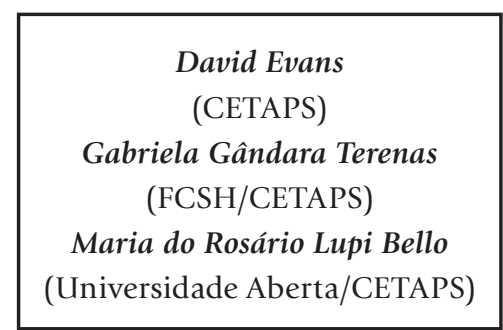

\section{Introdução}

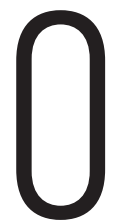

presente trabalho insere-se no âmbito do Projecto Portrayals of the Peninsular War: from the Novel to the Screen, o qual, por seu turno, constituiu uma das várias linhas de investigação do Grupo Anglo-Portuguese Studies sedeado no CETAPS (Centre for English, Translation and Anglo-Portuguese Studies).

O projecto foi fundado em 2006, no contexto da evocação do bicentenário da Guerra Peninsular, por David Evans, Gabriela Gândara Terenas e Maria do Rosário Lupi Bello, a cujo grupo se associou posteriormente Maria de Deus Duarte, tendo tido como objectivo primeiro o levantamento de todos os romances e filmes, portugueses e britânicos, cuja acção se desenrolasse ao tempo das Invasões Napoleónicas. Numa segunda fase, passou-se à análise das relações luso-britânicas,

1. Uma versão deste texto foi apresentada no II Congresso de Estudos Anglo-Portugueses realizado em 2011. 
tal como foram percepcionadas por romancistas de duas nacionalidades diferentes. E, por último, quase sempre de forma concomitante, os membros do Projecto debruçaram-se sobre os processos de adaptação de episódios e personagens dos romances ao ecrã.

Vários foram os trabalhos, apresentados individualmente ou em grupo, que, desde então foram levados a cabo. ${ }^{2}$ Entre estes devem destacar-se duas comunicações conjuntas, a primeira apresentada no Colóquio Internacional "Não vi o Livro, mas li o Filme", realizado na Faculdade de Letras da Universidade de Lisboa, em Abril de 2007, sob o título "Da Visão Literária da Guerra à sua Leitura Fílmica: as Invasões Napoleónicas no Cinema em Portugal"; e a segunda apresentada no Congresso Internacional e Interdisciplinar Evocativo dos 200 Anos da Guerra Peninsular, realizado na Fundação Calouste Gulbenkian, em Novembro de 2007, sob o título "Representações da Guerra Peninsular: do Romance ao Ecrã". Para além de várias participações em Colóquios Nacionais e Internacionais realizados em Portugal, Espanha e França, e mais de uma dezena de trabalhos publicados, em Setembro de 2008 foi ainda proferida uma conferência no âmbito do XVIII Curso de Verão do Instituto de História Contemporânea da Faculdade de Ciências Sociais e Humanas da Universidade Nova de Lisboa subordinado ao tema Os Tempos da Guerra Peninsular - 1808-1812. Uma Guerra Europeia Decidida em Terras Portuguesas.

$\mathrm{O}$ estudo agora apresentado tem como objectivo primordial a análise das representações dos dois chefes militares inimigos - Wellington e Napoleão - nos romances e nos filmes portugueses e britânicos. Trata-se, portanto, de avaliar, por um lado, a forma como os autores percepcionaram estas duas grandes figuras da Guerra Peninsular e, por outro, de analisar o modo como as mesmas foram retratadas no ecrã, contribuindo, deste modo, para a reconstituição de uma época particularmente significativa no contexto das relações anglo-portuguesas.

Assim, uma primeira parte será dedicada a reflexões mais gerais relativas às representações da Guerra no romance e no ecrã. A segunda parte será dedicada mais especificamente à análise das

2. V. Bibliografia. 
múltiplas formas através das quais as narrativas literárias e fílmicas que cruzam as realidades portuguesa e britânica retrataram os dois grandes chefes militares inimigos, figuras incontornáveis da História do século XIX.

\section{Parte I] A Guerra Peninsular do Romance ao Ecrã}

\section{A Guerra em Narrativas Portuguesas e Britânicas}

É vasta a diversidade de textos ficcionais publicados por autores portugueses e britânicos cuja acção se desenrola ao tempo das Guerras Napoleónicas. As primeiras narrativas surgiram ainda durante o conflito e, depois dele, muitos outros romances têm vindo a ser publicados até aos dias de hoje, tanto em Portugal como na Grã-Bretanha. ${ }^{3}$ Conscientes das complexidades das relações entre a História e a Literatura, os autores dos romances portugueses e britânicos apresentam várias características e preocupações comuns, embora difiram em alguns aspectos. Uma dessas características comuns, verificável sobretudo nas narrativas publicadas nos séculos XIX e XX, é a sua intenção moralista e didáctica expressa de formas diversas, mas sempre presente: o respeito pelo inimigo em campo de batalha; a misericórdia e a capacidade de perdoar perante um ser humano moribundo; o apelo à paz entre as nações mais poderosas do mundo; e, sobretudo, a exortação ao sentido de honra e de patriotismo, aliada a uma certa crítica à sociedade coeva, mediante a evocação de episódios passados.

Também cientes da dificuldade inerente à tentativa de congraçar plenamente factos autênticos com ficção, levando a que adequadamente uns se diluíssem noutros de forma harmoniosa, muitos dos autores recorriam a uma panóplia de artifícios destinados a envolver em verosimilhança, acção, personagens e cenários. Um desses recursos, decorrente de uma prática usual na novelística do século XIX, consistia em instaurar um primeiro narrador, alegadamente contemporâneo dos acontecimentos e neles envolvido. A sua função

3. Cf. a propósito Terenas, 2012. 
resumir-se-ia a relatá-los ao narrador principal, assim conferindo uma caução testemunhal ao enredo e, através daquele, apontar ao leitor o seu próprio papel perante o ocorrido.

Na realidade, em vários romances portugueses e britânicos - sobretudo os dedicados ao público juvenil - a principal preocupação dos autores/narradores era conferir autenticidade aos episódios narrados e procurar sempre, de algum modo, unir o útil (a instrução) ao agradável (o entretenimento), uma fórmula geralmente eficaz e de sucesso em qualquer época.

No respeitante às formas de representação da Guerra, ou seja, de acontecimentos desenrolados em Portugal ao tempo das Invasões Napoleónicas, nas narrativas portuguesas e britânicas, pode afirmar-se que, grosso modo, aqueles surgiram no decorrer da acção fictícia, nomeadamente em diálogos travados entre as personagens, estratégia relacionada com a trama dos romances. Resultaram também da (re)efabulação dos factos com vista ao engrandecimento dos heróis ou à valorização das aventuras vividas pelas personagens. No entanto, não raro, esses factos foram especificamente referidos pelos autores/narradores de duas outras formas, resultando em outros tantos processos de proporcionar verosimilhança à acção: em excursos dedicados exclusivamente a conferir informação de carácter histórico, o que confirma o objectivo didáctico, sobretudo visível nos romances portugueses e nas narrativas vitorianas de aventuras; e em notas de cariz erudito, apresentadas em rodapé ou no final dos romances, demonstrativas da preocupação de fidelidade aos acontecimentos por parte dos autores.

Em relação às principais diferenças entre os romances portugueses e britânicos, deve mencionar-se a técnica do folhetim, utilizada pelos primeiros, mas não pelos segundos, e a especificidade das fontes dos autores de além-Mancha.

Tão vulgarizada ao tempo através da imprensa periódica, ${ }^{4}$ a técnica do folhetim foi muitas vezes utilizada nas narrativas portuguesas da segunda metade de Oitocentos, sobretudo na passagem de um capítulo para outro. Apesar de o intuito ser o de escrever um "romance histórico", os autores não resistiam à utilização de uma

4. Cf. a propósito Terenas, 2004, vol. I: 49-206. 
prática popular, de comprovado sucesso junto do público leitor, que quase todos os escritores em causa teriam interiorizado devido à sua colaboração, mais ou menos assídua, no periodismo coevo. Tratava-se do artifício geralmente conhecido pelo termo inglês cliffhanger, segundo o qual, no fim de cada capítulo (correspondendo este a um episódio de folhetim) se deixava em suspenso o leitor quanto ao desfecho de um momento particularmente tenso ou empolgante da acção, o qual encontraria o seu desenlace no capítulo (ou folhetim) seguinte. ${ }^{5}$

Contrariamente aos portugueses, que recorreram à historiografia das Invasões Francesas para a construção das suas narrativas ficcionais, ${ }^{6}$ a maioria dos romancistas de além-Mancha baseou-se sobretudo nos relatos de cariz memorialístico publicados por militares britânicos que participaram nos acontecimentos ocorridos em Portugal e em Espanha ao tempo da Guerra Peninsular. ${ }^{7}$ A memória - individual ou colectiva - institui-se, assim, nestes textos, enquanto fonte da própria História. Guardiã de algo que efectivamente ocorreu no tempo, a memória contribui para uma melhor compreensão do passado, mas também, e sobretudo, do presente, do momento da escrita. Assim, à semelhança do que muitos historiadores da Guerra Peninsular fizeram outrora (e, aliás, continuam a fazer na actualidade $\left.^{8}\right)$, também os romancistas britânicos se socorreram de textos

5. Note-se que algumas narrativas portuguesas do século XIX e do início do século XX foram publicadas em folhetim antes de serem editadas em livro.

6. Entre as fontes mais citadas encontravam-se vários títulos em português, mas também alguns em francês. Entre os primeiros devem referir-se os seguintes: os periódicos Diário do Porto (1809) e O Observador Português Histórico e Político de Lisboa (1809); História da Invasão dos Franceses em Portugal e da Restauração deste Reino (s.d.) de José Acúrsio das Neves; Sucessos de Portugal ou Prodigiosa Restauração da Lusitânia Feliz. Por um Português (1809); História de Napoleão Bonaparte (1846) por Caetano Lopes de Moura; Excertos Históricos e Colecção de Documentos relativos à Guerra denominada da Península (1863-1882) de Cláudio Chaby; História da Guerra Civil e do Estabelecimento do Governo Parlamentar em Portugal (1870-1893) de Luz Soriano; A Guerra Peninsular (1874) de Pinheiro Chagas; e História Popular da Guerra da Península (1915) por J.J. Teixeira Botelho. Relativamente às fontes em francês destacam-se os seguintes títulos: Relation de l'Expédition du Portugal faite en 1807 et 1808 (1817) pelo general barão Thiébault; Histoire de la Guerre d'Espagne et du Portugal sous Napoléon (1829) pelo General Foy; Memóires de Madame la Duchesse d'Abrantes (1831-1835); e Histoire du Consulat de l'Empire (1845-1862) de M.A. Thiers.

7. Sobre esta matéria veja-se Terenas, 2000.

8. Vejam-se, por exemplo, os trabalhos de António Ventura e de Teresa Caillaux de Almeida, publicados sob os títulos Linhas de Torres Vedras. Memórias Francesas sobre a III Invasão e Memória das Invasões Francesas em Portugal, respectivamente. 
de cariz memorialístico, escritos por testemunhas oculares, com o intuito de (re)construir mentalidades, ambientes, episódios e personagens. Os livros de notas, os diários, as cartas e as memórias dos militares britânicos que combateram na Península serviram, deste modo, de ponto de partida para a (re)construção de outras narrativas de fundo histórico, mas cujos objectivos últimos se encontram intimamente relacionados com as especificidades dos autores, os objectivos da escrita e os horizontes de expectativa dos diferentes públicos a que se dirigiam.

Em comparação com os portugueses, os autores britânicos evidenciavam uma preocupação menor com as fontes históricas, talvez por se reportarem a um país que não era o seu e cujo passado seria mal conhecido entre o público-alvo. Todavia, Bernard Cornwell, por exemplo, no final das suas narrativas, apresentava ao leitor uma "Historical Note", na qual aludia à origem das suas informações, nomeadamente os relatos de militares, mas também A History of the Peninsular War (1902-1930) de Charles Oman ou ainda Wellington's Peninsular War (1990) de Julian Paget. Para além disso, Cornwell também teve, quase sempre, a preocupação de distinguir entre os dados recolhidos nas fontes históricas e o que fora exclusivamente fruto da imaginação. ${ }^{9}$

\section{A Guerra no Ecrã}

A relação do cinema com a realidade levanta inúmeras questões, tanto do ponto de vista da sua análise estética quanto no respeitante à sua capacidade de testemunhar o real. Na verdade, como afirmou o realizador russo e teórico do cinema Andrei Tarkovsky, "a força do cinema (...) está na relação necessária e inseparável com a matéria da realidade que nos circunda a cada instante. O tempo, fixado nas suas formas e nas suas manifestações factuais: tal é a ideia de base do cinema enquanto arte (...)". (1989: 60) Esta característica intrínseca à Sétima Arte, que a distingue de outras formas artísticas, ou seja,

9. Outras fontes inglesas frequentemente mencionadas foram as cartas oficiais redigidas por Wellington e por Beresford. 
o facto de não poder deixar de captar os índices exteriores de uma realidade dinâmica, em movimento, torna-a particularmente apta ao registo dos acontecimentos, mas também especialmente capaz de transmitir visões e imagens construídas que se difundem, assim, com grande força persuasiva como sendo verdadeiras.

Esta apetência "realista" do cinema, que assenta na reprodução de dados naturais, confere-lhe, à partida, uma posição privilegiada, e de particular responsabilidade, para o registo documental, diferentemente da literatura, que tem de usar as convenções estabelecidas e arbitrárias e, portanto, artificiais, da língua para se exprimir, com as quais constrói esse "outro mundo possível" que habita os contos e romances.

Desde cedo que os realizadores perceberam que o potencial contido no registo do real poderia ser usado com finalidades bem distintas. Rapidamente se desenharam, assim, duas tendências antagónicas: por um lado, aqueles que afirmavam a sua intenção clara de interferência no real, quer através da criação de imagens de fantasia e sonho, como começou por fazer Georges Méliès, quer através da inversão do ímpeto realista do cinema, construindo, através da montagem, situações "aparentemente" realistas, mas na verdade totalmente fabricadas, como foi o caso de Sergei Eisenstein, que apostou na força de intervenção ideológica do cinema. Por outro lado, veio a desenvolver-se, com o grande teórico André Bazin (e todos os que o seguiram), a defesa do realismo cinematográfico, através da afirmação de não interferência. $\mathrm{O}$ que se pretendia não era tanto a criação do que poderia ou deveria acontecer quanto o registo daquilo que a realidade é. Este cinema pretendia assim, sem perder a sua capacidade de transfiguração estética, colocar-se ao serviço da descoberta da essência escondida do real.

Ora o tipo de cinema que aqui interessa - filmes ficcionais de temática histórica - situa-se na fronteira entre estas duas grandes tendências: por um lado, assume a sua responsabilidade de testemunho histórico (portanto busca registar fielmente aquilo que a realidade "é"), mas, por outro, encontrando-se entre o documentário e a ficção, não resiste a fazer ver aquilo que poderia ou deveria ter sido, segundo as suas exigências de atracção estética, a necessidade mais pragmática de captação de audiências ou mesmo as imposições de cariz político ou ideológico que se encontram na sua base. 
Lidando com figuras e factos que tiveram existência real, estes filmes penetram num território altamente sensível, tal como acontece, aliás, com as narrativas literárias de idêntica temática, mas aqui com a agravante de a imagem parecer conferir ao que acontece o indelével selo da veracidade. Por outro lado, quanto mais um acontecimento foi decisivo e teve incidência universal, tanto mais é considerado como património da humanidade e, portanto, a sua representação deve acautelar essa espécie de "direitos de autor" mundiais.

Portanto, afigura-se mais do que justo procurar verificar de que forma tais filmes cumpriram ou não essa missão implícita na sua natureza: a de transmitir com fidelidade aquilo que realmente aconteceu. Tal como se referiu atrás, essa verificação foi já levada a cabo pelo presente grupo de trabalho a propósito da Guerra Peninsular como um todo. Porém, desse conflito internacional ressaltaram essas duas figuras que, pela dimensão verdadeiramente mítica que atingiram, merecem uma atenção especial. É precisamente no cruzamento entre essa imagem persistente e resistente que é a da mitificação - e não há nada mais difícil do que procurar alterar as características de um mito - e o desejo de apuramento de uma verdade objectiva e histórica que, neste caso, o presente trabalho se enquadra.

Assim, torna-se muito significativo procurar descobrir o que se escolheu representar, e de que forma foi feito, bem como registar o que se ignorou.

Ora, não pode deixar de constituir motivo de alguma perplexidade a circunstância de, contrariamente à literatura, o cinema português ter dado muito pouco espaço à representação da Guerra Peninsular. Se tal facto pode inicialmente ser encarado como uma recusa, até certo ponto natural, em dar corpo a acontecimentos muito traumáticos da História de Portugal (não se pode esquecer que o cinema teve início no final do século XIX, apenas cerca de oitenta anos depois da Guerra Peninsular), a verdade é que nem nas décadas seguintes se encontrou a vontade de representação cinematográfica desse momento histórico. Possíveis razões desse apagamento poderão ser encontradas, antes de mais, nas características intrínsecas da Sétima Arte portuguesa - mais tendente à representação dramática e melodramática e à comédia de costumes do que aos filmes históricos e bélicos - bem como a uma certa incapacidade nacional de representar e "exportar" as imagens dos seus 
heróis e das suas façanhas. Na verdade, é significativo que a nível europeu se circunscreva habitualmente à figura de Lord Wellington a vitória contra o exército francês, como se tal mérito não devesse ser dividido com alguns dos melhores chefes militares portugueses (cujos nomes muitas vezes nem sequer são nomeados), com os seus exércitos e até com a população em geral, que foi capaz de um imenso sacrifício nessa guerra de "terra queimada" que devastou o território nacional. Só esta incapacidade propagandística - que tem, obviamente, na sua raiz, uma fragilidade política - pode explicar que a Guerra Peninsular seja vista, não raro, - sobretudo pela Grã-Bretanha actual - como uma guerra travada pelos espanhóis com o auxílio britânico.

No contexto de uma generalizada omissão por parte do universo português da imagem em movimento, em relação a este período histórico, existem, porém, algumas excepções. Antes de mais, o filme A Caçada do Malhadeiro, realizado em 1967 por Quirino Simões e baseado na narrativa breve homónima do Conde de Ficalho, ${ }^{10}$ a qual todavia não apresenta referências significativas sob o ponto de vista das relações luso-britânicas, nem da caracterização de Wellington ou de Napoleão. Mais tarde, nos anos oitenta e noventa do século $\mathrm{XX}$, encontram-se alguns casos soltos, como por exemplo: uma co-produção luso-franco-hispano-italiana de 1981, rodada em Portugal, e intitulada La Guerrillera, realizada por Pierre Kast; e dois telefilmes, um de 1990, pelo realizador José Fonseca e Costa, chamado $O$ Bloqueio, no seu título original Le Blocus, integrado na série televisiva francesa Napoléon et l'Europe, e outro por Joaquim Pinto, uma curta-metragem intitulada Para Cá dos Montes, datada de 1993 (e estreada na RTP2, em 22 de Novembro), de que foi co-produtora a RTP.

Embora nenhum dos dois chefes militares seja representado neste conjunto de produções fílmicas, vale a pena destacar as obras de Quirino Simões e de Joaquim Pinto, pelo facto de nelas se confirmar a possibilidade de leitura a que acima nos referimos, ou seja,

10. Francisco Manuel de Melo Breyner (1837-1903), Conde de Ficalho, foi historiador de botânica em Portugal, escreveu uma biografia de Garcia de Orta e outra de Pêro da Covilhã. Foi também ficcionista, distinguindo-se com a obra Uma Eleição Perdida, publicada em 1888, que contém a novela do mesmo nome, e alguns contos regionais de ambiente alentejano, como este a que nos referimos, passado durante a Guerra Peninsular. 
a profundidade do trauma que as invasões francesas significaram para o povo português e a forma como Portugal sublimou esse sofrimento em narrativas que, do ponto de vista visual, preferiram dar a ver o drama humano (o sofrimento das populações que vêem entrar em suas casas, homens violentos que roubam, violam e matam) em vez de decidirem aproveitar o seu potencial de intriga e de acção bélica. ${ }^{11}$

De qualquer modo, torna-se fundamental relembrar que Napoleão nunca pisou solo português e que, portanto, só a figura de Wellington podia ter dado azo a representações cinematográficas da guerra em território nacional. Mas tal não acontece em qualquer dos filmes citados. Só viria a acontecer, por via indirecta, através dos filmes estrangeiros (muitos com participação britânica) estreados em Portugal, que acabaram por ser, ao lado das narrativas literárias, o veículo de transmissão de uma determinada visão da guerra e dos seus principais chefes.

11. De facto, o filme, baseado na narrativa do Conde de Ficalho, cuja acção segue no essencial (só alterando alguns dados de natureza secundária) o conto, a história de uma família de camponeses que vê entrar em sua casa cinco militares franceses, os quais - com excepção de um deles, que aliás, e significativamente, afirma não ser francês - violam a filha da família. Perante tal violência, pai e filho partem em perseguição dos soldados, vindo a matá-los um a um, acabando por sobreviver apenas aquele que afirmara ter outra nacionalidade, e a quem o irmão da rapariga tinha oferecido uma bebida, sabendo, portanto, não ter entrado no quarto da irmã e estar inocente desse crime. $\mathrm{O}$ filme resulta num libelo humanista sobre a possibilidade do perdão em condições extremas como a da guerra, ao mesmo tempo que sublinha o sofrimento de um povo que viu entrar na sua própria casa esse inimigo brutal que viola as mulheres e desrespeita os valores mais sagrados. O "francês" torna-se, aqui, o símbolo do mal, sendo atribuída ao povo a capacidade de fazer justiça com as próprias mãos, já que não bastava que os chefes militares ganhassem batalhas, era necessário que a população lidasse, no terreno, com as consequências mais cruéis das invasões. Joaquim Pinto pegou precisamente nesta ideia, embora com maior distância temporal, captando as memórias presentes no povo português nos dias de hoje. Neste caso, trata-se de uma ficção de vinte e seis minutos baseada em depoimentos colhidos junto de pessoas idosas na aldeia de Seara Velha (concelho de Chaves), que afirmaram estarem enterrados na aldeia dois soldados das tropas napoleónicas que se perderam e foram mortos pela população. O realizador aproveitou esta informação e cruzou-a com a das histórias e lendas referentes ao Vinho dos Mortos - um vinho da região que envelhece enterrado nos campos - associando-o, assim, a esse passado que, apesar de enterrado, continua presente no imaginário popular. 


\section{Parte II] Representações de Wellington e de Napoleão}

\section{Nas Narrativas Ficcionais}

Vários foram os romances portugueses e britânicos que representaram, de alguma forma, os dois grandes chefes inimigos: Wellington e Napoleão. De um conjunto de cerca de quarenta narrativas literárias sobre a Guerra Peninsular cuja acção se desenrola total ou parcialmente em território nacional, foram seleccionadas treze portuguesas e quinze britânicas, nas quais se encontraram referências significativas a estas duas figuras da história e da ficção: O Sargento-Mor de Vilar. Episódios da Invasão dos Franceses em 1809 (1863) $)^{12}$ de Arnaldo Gama; ${ }^{13}$ O Segredo do Abade (1864) do mesmo autor; A Casa dos Fantasmas. Episódio do Tempo dos Franceses $(1865-1866)^{14}$ de Luís Augusto Rebelo da Silva;15 O Major Napoleão $(1867)^{16}$ de Manuel Joaquim Pinheiro Chagas, ${ }^{17} \mathrm{O}$ Anel Misterioso. Romance $(1873)^{18}$ de Alberto Pimentel; ${ }^{19}$ Os Homens da Cruz Vermelha. Romance Histórico

12. A obra será adiante referida apenas por O Sargento-Mor de Vilar. Note-se que antes de ser editado em livro, o romance de Arnaldo Gama foi publicado em folhetim no Comércio do Porto, em 1964. A edição utilizada foi a de 1951.

13. Jornalista e escritor, Arnaldo de Sousa Dantas da Gama (1828-1869) distinguiu-se sobretudo como autor de romances históricos. Entre estes, para além das obras em análise, mencionem-se os seguintes títulos: Um Motim há Cem Anos (1861), A Última Dona de S. Nicolau (1866), O Filho do Baldaia (1866), A Caldeira de Pêro Botelho (1867) e ainda Balio de Leça (1872).

14. A obra será adiante referida apenas por A Casa dos Fantasmas.

15. Jornalista e escritor prolífico, Luís Augusto Rebelo da Silva (1822-1871) abriu novos caminhos à narrativa histórica, sobretudo a partir de 1848. Distinguiu-se nos estudos históricos e literários, na dramaturgia, em traduções e em biografias. Entre os seus romances históricos destacam-se $A$ Tomada de Ceuta (1840), Ódio Velho não Cansa (1848-1849), A Mocidade de D. João V (1852-1853) e Lágrimas e Tesouros (1863).

16. Deve notar-se que quatro dos dezassete capítulos que constituem a edição utilizada (de 1867) foram publicados em folhetim, no mesmo ano, primeiro nos números 1 e 2 do periódico Enciclopédia Popular (Lisboa, 1867-1868) e, depois, do número 1826 ao número 1833 da Gazeta da Figueira (Figueira da Foz, 1887-1925). Ainda em 1867 foi publicada uma separata com os mesmos dezassete capítulos, sob o título O Monge do Buçaco. Episódio da Invasão Francesa (s.l.).

17. Notável polígrafo, Manuel Joaquim Pinheiro Chagas (1842-1895) distinguiu-se como escritor, jornalista, político, orador, dramaturgo e tradutor. Entre as suas narrativas históricas destacam-se Tristezas à Beira-Mar (1866), Novelas Históricas (1869), A Máscara Vermelha (1873), Um Melodrama em Santo Tirso (1873), A Varanda de Julieta (1876) e A Mantilha de Beatriz (1878).

18. A obra será adiante referida apenas por $O$ Anel Misterioso. A edição utilizada foi a de 1945 .

19. Jornalista, político e escritor, Alberto Augusto de Almeida Pimentel (1849-1925) foi autor de vários romances entre os quais se destacam A Virtude de Rosina (1872), A Porta do Paraíso (1873), Um Conflito na Corte (1875), Rainha sem Reino (1887) e As Amantes de D. João V (1892). 
ao Tempo dos Franceses (1879-1880) ${ }^{20}$ de Carlos Pinto de Almeida; ${ }^{21}$ No Tempo dos Franceses. Romance Histórico $(1894)^{22}$ de Francisco da Fonseca Benevides; ${ }^{23}$ Paixão de Maria do Céu (1902) ${ }^{24}$ de Malheiro Dias; ${ }^{25}$ A Filha do Polaco. Romance Histórico (1903) ${ }^{26}$ de António de Campos Júnior;, ${ }^{27} \mathrm{O}$ Moleiro de Sula (1954), ${ }^{28}$ um conto da autoria de Júlio Dantas; ${ }^{29}$ O Mutilado de Ruivães. Romance. (Das Invasões Francesas às Lutas Civis) (1980) ${ }^{30}$ da autoria conjunta de Mário Moutinho e A. Sousa e Silva, acerca de quem pouco se sabe; O Amor em Armas.

20. A obra será adiante referida apenas por Os Homens da Cruz Vermelha.

21. Orientalista e forte crítico da Igreja Católica, Carlos Pinto de Almeida (1831-1899) publicou vários romances históricos em volume e em folhetim, no Diário de Notícias, no qual foi colaborador. Entre eles destacam-se os seguintes títulos: A Conquista de Lisboa (1866), A Cruz pelas Riquezas (1867), O Irmão Bastardo (1868), O Mestre de Avis (1878) e Os Conspiradores (1879).

22. A obra será adiante referida apenas por No Tempo dos Franceses. A edição utilizada foi a de 1908

23. Francisco da Fonseca Benevides (1835-1911) foi professor de Física, no Instituto Comercial e Industrial de Lisboa, do qual foi director e onde organizou um importante museu tecnológico. Leccionou também as cadeiras de Mecânica e Artilharia e Hidrografia na Escola Naval. Colaborou assiduamente em vários dos periódicos do seu tempo e foi sócio efectivo da Academia das Ciências de Lisboa e da Academia Real de História de Madrid. Publicou variadíssimos trabalhos relacionados com as áreas das cadeiras leccionadas e ainda relatórios das exposições visitadas. Do conjunto da sua obra destacam-se dois estudos de algum modo relacionáveis com as temáticas tratadas no romance seleccionado para análise: Rainhas de Portugal (1878-1879) e O Real Teatro de São Carlos (1883, 1902).

24. A edição utilizada foi a de 1982.

25. Jornalista, deputado, cronista, dramaturgo e romancista, Carlos Malheiro Dias (1875-1941) exilou-se no Brasil, nos finais de 1913, onde desenvolveu grande parte da sua actividade literária. De entre as suas obras ficcionais de maior relevo destacam-se Filho das Ervas (1900), Os Teles de Albergaria (1901) e A Vencida (1907). No respeitante à sua actividade como cronista sublinham-se as Cartas de Lisboa (1904-1906) e O Estado Actual da Causa Monárquica (1913). Escreveu ainda duas peças de teatro: O Grande Cagliostro (1905) e Inimigos (1913).

26. A obra será adiante referida apenas por A Filha do Polaco. Note-se que antes de ser editado em volume, o romance foi publicado em folhetim no jornal O Século. Até 1960 a obra teve pelo menos cinco edições, pelo que podemos afirmar que, sensivelmente durante a primeira metade do século XX, se tratou de um best-seller. A edição utilizada foi a de 1945.

27. Romancista, jornalista, dramaturgo e militar, António Maria de Campos Júnior (1850-1917) nasceu em Angra do Heroísmo, viveu muitos anos na Marinha Grande onde casou e veio a falecer. Estudou em Leiria, onde escreveu os seus primeiros trabalhos, e por interferência do seu amigo Afonso Lopes Vieira (pai do poeta) foi para Lisboa onde desenvolveu grande actividade literária, jornalísticas e política. Escreveu vários romances históricos de entre os quais se destacam, para além da obra em apreço, os seguintes títulos: O Marquês de Pombal (1899), Luís de Camões (1900), Guerreiro e Monge (1910), Rainha Madrasta (1911) e Os Últimos Amores de Napoleão (s.d.).

28. A edição utilizada foi a de 1961.

29. Da vastíssima obra de Júlio Dantas (1876-1962), destacam-se Pátria Portuguesa (1913), uma colectânea de contos onde se encontram "O Tambor" e "O Joanico", ambos com referências à Guerra Peninsular.

30. A obra será adiante referida apenas por O Mutilado de Ruivães. 
Romance (2009), ${ }^{31}$ de José Marques Vidal;32 e, por último, Vencer ou Morrer (2010) ${ }^{33}$ de Mendo Castro Henriques. ${ }^{34}$

Relativamente às narrativas de fundo histórico escritas por autores britânicos incluem-se as seguintes: Charles O'Malley. The Irish Dragoon (1841) ${ }^{35}$ de Charles Lever; ${ }^{36}$ The Young Buglers. A Tale of the Peninsular War (1880) $)^{37} \mathrm{e}$ With Moore at the Corunna. A Tale of the Peninsular War (1897) $)^{38}$ ambas da autoria do militar vitoriano G.A. Henty; ${ }^{39}$ The Spy. A Tale of the Peninsular War and the Storming of Badajoz, Founded Upon the Personal Memoirs of Sir Jeffrey Jones, Bart., of Heatherford Hall in Hampshire (1898), ${ }^{40}$ da autoria do Major Charles Gilson; ${ }^{41}$ Lads of

31. A obra será adiante referida apenas por O Amor em Armas.

32. José Marques Vidal nasceu em 1930, em Lamas do Vouga, Águeda, licenciou-se em Direito e teve uma longa e diversificada carreira jurídica. Ocupou vários cargos nos círculos judiciais de norte a sul de Portugal, desde delegado do procurador da República a juiz conselheiro do Supremo Tribunal Administrativo. A par da carreira de magistrado, Marques Vidal tem publicado vários livros de cariz jurídico e de ficção.

33. Trata-se do primeiro volume (o único até agora publicado) de uma trilogia.

34. Doutor em Filosofia, Mendo Castro Henriques tem uma vasta obra publicada da qual se destacam os títulos Salamanca 1812 (2002) e Vitória e Pirinéus (2009).

35. A obra será adiante referida apenas por Charles $O^{\prime}$ Malley.

36. Charles Lever (1806-1872) nasceu em Dublin, filho de um arquitecto. Estudou no Trinity College e, depois, em Göttingen onde se formou em Medicina. Durante a epidemia de cólera, que alastrou pela Irlanda em 1832, desenvolveu um trabalho notável com os doentes infectados. Depois do seu casamento, com Catherine Baker, foi viver para Bruxelas, onde se dedicou à prática da medicina, sobretudo entre os membros da comunidade britânica. De entre as suas obras, destacam-se os seguintes títulos: Confessions of Harry Lorrequer (1839), Jack Hinton (1843), Arthur O'Leary (1844), Tom Burke of Ours (1844), Horace Templeton (1848) e Con Cregan (1849).

37. A obra será adiante referida apenas por The Young Buglers. A edição consultada foi a de 1954 .

38. A obra será adiante referida apenas por With Moore at Corunna. A edição consultada foi a de 2001.

39. Depois de completar os seus estudos, primeiro em Westminster School e depois na Universidade de Cambridge, George Alfred Henty (1837-1901), que viveu no reinado da Rainha Victoria, levou uma vida cheia de aventuras, muitas delas relacionadas com acontecimentos históricos de cariz bélico. Enquanto militar ao serviço do exército britânico participou na Guerra da Crimeia; foi correspondente de guerra em Itália ao tempo de Garibaldi e testemunha ocular da Guerra Franco-Prussiana. Os heróis dos seus romances são geralmente jovens do sexo masculino, corajosos, inteligentes e patriotas, cujas aventuras se desenrolam durante períodos relevantes da História. Entre as suas publicações, para além dos romances em apreço, contam-se, entre outros, os seguintes títulos: Cornet Horse. A Tale of the Marlborough's Wars (1881), One of the 28 ${ }^{\text {th }}$. A Tale of Waterloo (1889), Through Russian Snows. A Story of Napoleon's Retreat from Moscow (1896) ou At Aboukir and Acre. A Story of Napoleon's Invasion of Egypt (1896). Dedicadas a um público juvenil, as obras contêm ilustrações legendadas, representativas de episódios dos romances.

40. A obra será adiante referida apenas como The Spy. A edição consultada foi a de 1936.

41. Charles James Louis Gilson (1878-1943) tornou-se conhecido pelas suas narrativas de aventuras para rapazes, muitas delas de fundo histórico. Entre elas destacam-se os seguintes títulos: The Lost Empire. A Tale of Many Lands (1910), The Lost Column. A Story of the Boxer Rebellion (1912); The Sword of Freedom. A Story of the English Revolution (1912) e In Arms for Russia (1918). 


\section{REAP/JAPS 26}

\section{the Light Division. A Tale of the Peninsular War (1909) ${ }^{42}$ pelo Tenente- -coronel Mockler-Ferryman; ${ }^{43}$ The Snare (1917), de Rafael Sabatini; ${ }^{44}$}

42. A obra será adiante referida apenas como Lads of the Light Division. A edição consultada foi a de 1992.

43. Augustus Ferryman Mockler-Ferryman (1856-1930) nasceu em Dublin, estudou na Cheltenham College e, depois, na Royal Military College de Sandhurst, tendo integrado o $43^{\circ}$ Regimento de Infantaria Ligeira em 1877. Entre 1889 e 1890 exerceu o cargo de secretário privado do Comissário Especial da HBM (Her Britannic Magesty) para o Níger. Em 1891 casou com Evelyn Whitehead. Foi professor de fortificações e de topografia na academia de Sandhurst, entre 1892 e 1900. Entre 1903 e 1905 trabalhou no War Office, onde colaborou na história oficial da Guerra dos Bóeres. De entre as suas obras publicadas destacam-se os seguintes títulos: Imperial Africa: the Rise, Progress and Future of the British Possessions in Africa (1898), British West Africa: Its Rise and Progress (1900), British Nigeria: a Geographical and Historical Description of the British Possessions Adjacent to the Niger River, West Africa (1902), Military Sketching and Reconnaissance (1903) e The Life of a Regimental Officer During the Great War, 1793-1815, Compiled from the Correspondence of Colonel Samuel Rice and from Other Sources (1913).

44. Rafael Sabatini (1875-1950) nasceu em Jesi, Itália, filho de dois conhecidos cantores de ópera à época, Anna Trafford, uma inglesa oriunda da zona de Liverpool, que era também pianista, e Vicenzo Sabatini, italiano. Até aos dezassete anos, Rafael viveu em vários países europeus, nomeadamente em Itália, Inglaterra, Portugal e Suíça, o que lhe permitiu aprender diferentes línguas: o italiano, o inglês, o português, o francês e o alemão. Desde cedo que se revelou um leitor entusiasta de Shakespeare, Scott, Dumas, Verne, Manzoni e ainda do historiador norte-americano William Prescott. Em 1892, Sabatini deixou os estudos e foi para Liverpool trabalhar como tradutor. Por volta de 1895 começou a escrever contos por considerar que era mais divertido escrevê-los do que lê-los. Os seus primeiros textos narrativos, actualmente desaparecidos, terão sido publicados num periódico local. No entanto, a partir de 1899 começou a vender as suas histórias para revistas com projecção nacional, como a Pearson's Magazine, a London Magazine e a Royal Magazine. Em 1901 assinou um contrato para escrever o que viria a ser o seu primeiro romance e, em 1905, aquando da publicação do segundo, abandonou o emprego e dedicou-se exclusivamente à escrita, passando a escrever um livro por ano, um ritmo de produção que manteve até adoecer. Em 1921 saiu o seu primeiro grande sucesso, Scaramouche cuja acção decorre ao tempo da Revolução Francesa e que rapidamente se tornou um best-seller internacional. Captain Blood (1922) foi um sucesso ainda maior e, neste contexto auspicioso, os seus livros anteriores foram reimpressos, sendo The Sea Hawk (1915) considerado o mais importante, talvez pela adaptação ao cinema, onde o papel principal foi interpretado por Errol Flynn. Em 1925, Rafael Sabatini era um homem rico: os seus livros tinham sido adaptados para o cinema e o teatro. Autor de trinta e um romances, oito colecções de contos, seis livros não ficcionais, uma peça de teatro e várias publicações dispersas, morreu na Suíça, em consequência de doença prolongada. 
Death to the French (1932), ${ }^{45}$ da autoria de C.S. Forester; ${ }^{46}$ Too Few for Drums (1964) ${ }^{47}$ de R.F. Delderfield ${ }^{48}$ Sharpe's Gold. Richard Sharpe and the Destruction of Almeida, August 1810 (1981), ${ }^{49}$ Sharpe's Enemy. Richard Sharpe and the Defence of Portugal, Christmas 1812 (1984), ${ }^{50}$ e Sharpe's Escape. Richard Sharpe and the Bussaco Campaign, 1810 (2003), ${ }^{51}$ todas incluídas na série The Complete Sharpe Collection, ${ }^{52} \mathrm{de}$

45. Em 1989, este romance foi publicado nos Estados Unidos sob o título Rifleman Dodd. A edição consultada foi a de 1956 .

46. Pseudónimo de Cecil Louis Troughton Smith, Cecil Scott Forester (1899-1966) nasceu no Cairo, quando o seu pai se encontrava ao serviço da Coroa britânica, ainda no período áureo do império. Estudou em Inglaterra e em 1937 foi correspondente de The Times durante a Guerra Civil de Espanha. Mais tarde partiu para os Estados Unidos, onde viveu até à data da sua morte. Fez longas viagens de barco à vela, em Inglaterra, França e Alemanha. Autor de vários romances de aventuras de fundo histórico, Forester celebrizou-se com a série Hornblower, publicada entre 1937 e 1967 , que alcançou um extraordinário êxito comercial. Trata-se de um conjunto de treze "romances marítimos" (seafaring novels) cuja acção decorre precisamente ao tempo das Guerras Napoleónicas, alguns dos quais foram adaptados para o cinema. Tendo como teatro de operações o mar, esta série desenrola-se em torno das aventuras do herói, Horatio Hornblower, cuja evolução Forester apresenta ao longo de emocionantes narrativas, que retratam a sua carreira na Marinha, desde uma idade muito jovem até se tornar famoso. Para além da obra que faz parte do corpus em análise no presente estudo, Forester publicou ainda um outro romance de aventuras cuja acção se desenrola em Espanha ao tempo da Guerra Peninsular: The Gun (1933). O tema da guerra, nomeadamente a de 1914-1918, deu ainda origem a Brown on Resolution (1929).

47. A edição consultada foi a de 1992 .

48. Ronald Frederick Delderfield (1912-1972) foi um romancista e dramaturgo muito popular em Inglaterra, onde várias das suas obras vieram a ser adaptadas para a televisão. Durante a infância viveu em Addiscombe, perto de Croydon (Surrey), onde frequentou uma pequena escola privada, que viria a inspirar a série "The Avenue Story". Em 1929, começou a trabalhar com o pai no jornal Exmouth Chronicle, tornando-se, mais tarde, editor do mesmo. Esta experiência profissional fornecer-lhe-ia material para a publicação de, pelo menos, dois romances: For My Own Amusement (1972) e Diana (1979). Desde cedo que Delderfild se interessou pelas Guerras Napoleónicas, tendo publicado vários textos de cariz ensaístico e historiográfico sobre este período. Terão sido, decerto, estes trabalhos que estiveram na génese da narrativa que integra o corpus do presente estudo. A maioria dos seus romances históricos baseia-se, todavia, nas experiências de jovens militares de regresso a casa, depois de combaterem ou na Primeira Grande Guerra ou nas guerras coloniais britânicas. Entre estes últimos contam-se a trilogia A Horseman Riding By (1966), Come Home Charlie and Face Them (1969), The God is an Englishman (1970) e o best-seller To Serve Them All My Days (1972 ).

49. A obra será adiante referida apenas como Sharpe's Gold. A edição consultada foi a de 1994 .

50. A obra será adiante referida apenas como Sharpe's Enemy. A edição consultada foi a de 1994 .

51. A obra será adiante referida apenas como Sharpe's Escape. A edição consultada foi a de 2004 .

52. Trata-se de um vasto conjunto de narrativas que têm como fio condutor as aventuras e expedições heróicas do protagonista Richard Sharpe e dos seus companheiros, desenroladas durante o período das Guerras Napoleónicas, mais precisamente entre 1799 e 1821. Deste conjunto de vinte e três romances, apenas os cinco títulos referidos se desenrolam, total ou parcialmente, em território português. 


\begin{abstract}
Bernard Cornwell;53 Fire and Sword (2009) inserida na série "The Wellington and Napoleon Quartet ${ }^{154}$ da autoria de Simon Scarrow; ${ }^{55}$ e, finalmente, Alone With Glory (2008), The Colour of Blood (2009) e A Different Kind of War (2010) todas da autoria de Peter Youds ${ }^{56}$ e inseridas no conjunto intitulado Ties of Blood. ${ }^{57}$

Passar-se-á agora à análise do modo como as narrativas seleccionadas focaram, com mais ou menos intensa ficcionalidade, os dois principais actores político-militares do conflito.
\end{abstract}

53. Autor bastante conhecido na Grã-Bretanha, sua terra natal, Bernard Cornwell tem sido muito divulgado não só nos Estados Unidos (onde reside actualmente), mas também em variadíssimos outros países. Depois de frequentar um colégio interno, Cornwell inscreveu-se na Universidade de Londres e tornou-se professor antes de optar pela carreira de jornalismo. Trabalhou na BBC, primeiro como investigador de programas e, mais tarde, como correspondente na Irlanda do Norte. Foi durante o período passado em Belfast que iniciou a sua carreira de escritor de narrativas de inspiração histórica. Os seus romances foram traduzidos para mais de dezasseis línguas, alcançando rapidamente o topo das listas dos livros mais vendidos. De acordo com alguns críticos, a chave do seu sucesso poderá residir numa cuidadosa pesquisa histórica, bem como na forma envolvente com que confere vida às suas personagens. Cornwell investiga exaustivamente o enquadramento histórico-geográfico dos seus romances, deslocando-se, inclusivamente, aos lugares onde ocorreram as batalhas descritas na série Sharp.

54. Constituída por quatro volumes - Young Bloods (2006), The Generals (2007), Fire and Sword (2009) e The Fields of Death (prelo) - a série retrata, de forma romanceada e em paralelo, as vidas dos dois grandes protagonistas das Guerras Napoleónicas: Bonaparte e Wellington. Os três primeiros volumes já foram traduzidos para português e publicados sob os títulos de Jovens Lobos (2008), Os Generais (2009) e A Ferro e Fogo (2010) respectivamente.

55. Simon Scarrow nasceu em 1962, na Nigéria, vivendo actualmente em Norfolk, Inglaterra. É também autor da série "Eagle", constituída, até ao momento, por nove volumes. Trata-se de um vasto conjunto de romances históricos sobre as legiões romanas, muitos dos quais já foram traduzidos para português.

56. Peter Youds nasceu em Cheshire, em 1954, onde foi educado, mas actualmente vive em Nottinghamshire. No início da sua carreira profissional trabalhou no teatro e nos jornais, dedicando-se depois à indústria do entretenimento, à qual ainda se mantém ligado.

57. Constituída até agora apenas por quatro romances, esta série acompanha as aventuras de dois meios-irmãos, Tom Herryck (dos Royal Engineers) e Robert Blunt (oficial da Infantaria Ligeira) desde 1808 até à batalha de Waterloo. 
1.1. "Lord Villainton", "o General de Sipaios", "o Fábio Britânico", "o Duque de Ferro", "Old Beaky", "the Conky", "the Nosy" "the Peer", "the Beau" ou "Old Arty": Sir Arthur Wellesley, Lord Wellington

Sob o ponto de vista da cronologia das Invasões Francesas, as primeiras referências a Sir Arthur Wellesley, no conjunto das narrativas portuguesas e britânicas em apreço, surgem em Vencer ou Morrer, logo aquando da passagem pelo Porto, a bordo do HMS Crocodile. Depois de desembarcar, Sir Arthur teria reunido, no Convento dos Bernardinos, com o Estado-maior do exército de Bernardim Freire de Andrade. À sua chegada ao edifício da Alfândega, o narrador retratou-o como um homem de estatura média, com menos de quarenta anos, de rosto comprido, fronte alta, nariz aquilino e olhos azuis-acinzentados. ${ }^{58}$ Esta caracterização física encontra o seu paralelo nos romances britânicos, onde Arthur Wellesley era geralmente descrito como um homem que se apresentava sempre impecavelmente vestido, de impenetráveis, mas argutos olhos azuis acinzentados, nariz adunco, boca elegante, mas que sorria pouco e "de má vontade", e com uma expressão facial que raramente (ou nunca) se alterava. Em qualquer lado onde aparecesse, ainda que rodeado por outros oficiais, o chefe britânico era facilmente reconhecido: pela excelência da montada, pela casaca azul ou cinzenta (em contraste com as casacas vermelhas e as plumas usadas pelos seus homens), pela gravata branca, pela postura digna, austera e autoconfiante e ainda pelo enorme e arrogante nariz, que lhe valeu a alcunha de "nosy" ou "conky":

58. V. Henriques, 2010: 101. 
'Old Nosey,' as we used to call him, was always immaculately dressed. His thin lips were ever closed. (...) There was more expression in his cravat than was ever to be seen in his face. (...)

I remember I saw him eating the drumstick of a chicken upon the beach of Mondego Bay. The first time I saw him in action was at Roliça. And I noted no change in the expression of his face, which, if it ever expressed anything, was one of superiority to all men and the world at large. On each occasion he was supremely calm; yet I know that he enjoyed that drumstick as much as he relished drubbing the French. (Gilson, 1898: 124) ${ }^{59}$

Sob o ponto de vista psicológico, o futuro Duque de Wellington era caracterizado, tanto nas narrativas britânicas como nas portuguesas, como um militar com qualidades excepcionais, cauteloso, pragmático, frio e determinado. Nas narrativas em português, estas características foram particularmente assinaladas antes das batalhas. Assim, antes do início da batalha do Vimeiro (travada em 21 de Agosto de 1808), por exemplo, Sir Arthur apresentava-se como o exemplo paradigmático das características atribuídas aos seus homens, tal como se pode constatar através da descrição de um momento em que o exército expedicionário britânico aguardava a aproximação dos franceses:

Sir Arthur Wellesley, nos exórdios da sua carreira na Península, logo revelou qualidades, que o habituaram a competir com os mais ilustres capitães sem desafiar um daqueles imensos desastres, que imortalizam nas páginas da epopeia napoleónica o infortúnio de tantos generais. Concedendo pouco, ou nada, ao acaso e não estribando as combinações nos rasgos duvidosos de temerárias empresas, concebera o seu plano com prudência fria, que sempre em tudo caracterizou os seus cálculos. (Silva, 1866, vol. II: $158-159)^{60}$

O mesmo se verificava nas narrativas britânicas, nas quais, durante os combates Wellesley era quase sempre visto calmo e imperturbável, montado a cavalo, tentando detectar os pontos fracos do

59. Veja-se também Sabatini, 1917: 154 e 226; e Lever, 1841: 237 e 245-246.

60. Veja-se também Silva, 1866,vol.II: 164; e Almeida, 1880, vol.IV: 441. 
inimigo, dando novas ordens aos seus homens e comandando-os com serenidade, mas muita firmeza. ${ }^{61}$ Concluída uma contenda e confirmada uma vitória, a postura de Wellesley mantinha-se inalterada, tal como o protagonista de The Spy relatava, a propósito do final da batalha da Roliça:

And then, a man, who had dragged his horse by bridle up the hill-side, mounted, not ten yards from where I lay. I looked up at him, and saw it was Wellesley, calm and serene as ever.

A staff officer held his stirrup as he swung into the saddle.

He sat for a moment, with both hands resting on the pommel, looking straight before him, with a fixed steady gaze.

Then he spoke; and there was not a shadow of emotion in his tones, though he flavoured his words with a strong oath than I care to set down here.

'We've done 'em, by gad. They're on the run!' (Gilson, 1898: 131)

Nas narrativas britânicas, Sir Arthur Wellesley era caracterizado, acima de tudo, como um militar motivado por um elevado sentido de dever, jamais abandonando as suas obrigações, e extremamente determinado: uma vez definidos os seus propósitos, levá-los-ia até ao fim, ultrapassando todos os obstáculos que porventura se colocassem à sua frente. ${ }^{62}$ Homem de poucas palavras, calmo, frio, altivo, era respeitado, idolatrado e aclamado pelos seus subordinados. ${ }^{63}$ Embora Wellington parecesse ignorar quaisquer manifestações de afecto ou louvor, no seu íntimo, todos sabiam que o comandante-chefe se preocupava genuinamente com os seus homens, tendo-lhes sempre dado provas inequívocas do apreço que por eles nutria. De acordo com o protagonista de The $S p y$, Wellington não procurava conquistar simpatias, olhando até com indiferença para os homens que davam vivas à sua passagem. No entanto, estes não só sabiam que ele prezava muito os seus soldados, como também tinham total

61. V. Gilson, 1898: 123, 125-126; e Youds, 2010: 165.

62. V. Scarrow, 2009: 200.

63. Deve notar-se que esta atitude por parte dos seus subordinados não encontra uma correspondência total na mais recente historiografia britânica, pois, de acordo com Charles Esdaile, por exemplo, Wellington podia ser injusto ou até cruel para com os seus homens, os quais, embora o respeitassem e nele confiassem, verdadeiramente não gostariam muito dele. Cf. Esdaile, 2009, vol. IV: 75-100. 
confiança no seu génio e capacidade de decisão, avançando para uma batalha seguros da vitória. Os homens tinham-se habituado de tal forma a respeitar-lhe as capacidades militares, a clareza das ideias e as opções estratégicas, que as ordens eram cumpridas sem qualquer contestação e as tomadas de posição acatadas sem hesitações. ${ }^{64}$

Não obstante esta postura distante, fria e altiva, Wellington foi caracterizado como um homem com grande sentido de humor, característica geralmente atribuída aos britânicos nas narrativas em português, mas que encontra o seu paralelo nos romances escritos em inglês. Assim, no conto de Júlio Dantas, O Moleiro de Sula, onde Wellesley surge como personagem, a propósito do seu aboletamento numa pequena cela do convento da Serra do Buçaco, por ocasião da batalha travada naquela região, o narrador descrevia a chegada de Sir Arthur aos seus aposentos, na companhia do Estado-maior, sublinhando justamente o pragmatismo e o sentido de humor que caracterizava o chefe dos exércitos aliados, até por oposição a uma atitude algo sobranceira atribuída a alguns dos seus generais:

Wellesley entrou pela portaria, de chapéu na cabeça; os generais seguiram-no, de roldão; apenas Craufurd (...) se lembrou de perguntar ao Prelado, atirando-lhe à cara baforadas de fumo, onde ficava o quarto de Lord Wellington. Frei Manuel pediu licença para os acompanhar, deteve-se diante da última porta da direita antes de chegar ao claustro, e, baixando os olhos, murmurou, confuso e humilde:

- É a minha cela. Não temos outra menos pobre para oferecer a Sua Ilustríssima.

- His Excellency! - emendou Picton, franzindo o sobrolho e enterrando o chapéu alto até às orelhas.

Quando se abriu a porta do quarto que a Comunidade destinara a Wellesley, os generais entreolharam-se. Era um rebaixo de telha vã, cavado na terra, que recebia luz de uma fresta de grades e onde só podia entrar dobrado pelos rins, lura de coelhos ou toca de animal bravio que os servos de Deus - desafeitos já a mimos na dureza e na miséria do cenóbio - tinham entretanto alindado, estendendo sobre o catre um pano de damasco

64. Veja-se Henty, 1880: 108; Gilson, 1898: 124; Forester, 1832: 1; Cornwell, 1981: 27 e 177; Cornwell, 1984: 343-344; e Youds, 2009: 54 e 103. 
vermelho trazido do arcaz da sacristia, enchendo de água pura um cantarinho de barro ressumante e deixando à vista - porque era a mais rica alfaia do aposento - o bispote de prata que as freiras de Lorvão lhes haviam mandado de presente quando, em tempo, se esperara no conventinho a visita da Rainha viúva de Inglaterra. Wellesley gostou da novidade - 'very well! Very well!' -, baixou a cabeça, entrou na cela onde dois homens não caberiam e, com aquela ponta de humor que caracteriza a história anedótica da bravura inglesa, convidou os generais a entrar e a sentarem-se para o Conselho. Todos se riram -, até os frades. (Dantas, 1961: 194) ${ }^{65}$

Da perspectiva dos britânicos, Wellington aliava o seu apurado sentido de humor a qualidades de um grande diplomata, embora nunca tivesse demonstrado muito talento como político. ${ }^{66}$ Teria sido, porventura essa falta de gosto pela política que lhe trouxera alguns dissabores junto dos governantes britânicos, os quais nem sempre teriam compreendido as atitudes de Sir Arthur Wellesley. ${ }^{67}$ Assim, de acordo com o protagonista de The Spy, Arthur Wellesley tinha um extraordinário sentido de humor e uma ironia muito peculiar, áspera e pungente, mas, acima de tudo, era um simples militar, talvez um pouco arrogante, mas com uma vontade de ferro. ${ }^{68}$

A chegada de Wellesley a Lisboa em 1809, por ocasião dos preparativos para o início da marcha em direcção ao Porto, reconstituída em Fire and Sword, The Colour of Blood e Vencer ou Morrer constitui um episódio emblemático, do ponto de vista da caracterização do comandante das forças aliadas, a dois níveis: a popularidade que alcançara junto dos portugueses; e a sua extraordinária capacidade de organização e de comando. Assim, os narradores dos romances citados sublinhavam o entusiasmo e as demonstrações de regozijo com que fora recebido pela população de todas as classes sociais, ao desembarcar em Lisboa, no dia 22 de Abril:

\footnotetext{
65. O estabelecimento do quartel-general de Wellington no Convento do Buçaco e o aboletamento de chefe militar britânico numa das celas foram aspectos também referidos por Youds, 2010: 151.

66. Este vector encontra correspondência total nos mais recentes trabalhos de cariz historiográfico, nos quais o crescimento da oposição à sua política, na Câmara dos Comuns, conduziria ao seu pedido de demissão do cargo de Primeiro-ministro em 1830. Cf. Vicente, 2006: 63-64.

67. V. Youds, 2010: 36.

68. V. Gilson, 1898: 124-125.
} 
No Terreiro do Paço ressoaram acalorados vivas e aclamações de grupos com guitarras e tambores. As damas acorreram em liteiras pintadas e de lenços brancos ao pescoço e xailes; os cavalheiros traziam os seus tricórnios decorados com fitas azuis e vermelhas e um lema escrito na frente - 'Vencer ou Morrer'. Havia camponeses de camisa branca e chapéu preto, vendedores de sardinha, de limonada, e os de castanha lançando o sal alto com a palma da mão; (...) cantores entoavam os feitos de Arthur Wellesley e mostravam-se quadros em que a Vitória colocava uma coroa de louros numa nobre cabeça de nariz aquilino!

Caíra no goto dos lisboetas o general, no qual sentiram a lucidez dos chefes e a determinação dos bravos. (...) Havia uma confiança geral no seu talento, a esperança de que se operaria uma mudança propícia, e o entusiasmo subiu ao rubro quando se soube que iria assumir o comando-geral de ambas as forças, britânicas e portuguesas. (Henriques, 2010: 191)

Se o narrador de Vencer ou Morrer associava este entusiasmo colectivo à celebração do espírito patriótico do povo português e à esperança de libertação do jugo napoleónico, o narrador de Fire and Sword, por seu turno, ao relatar os mesmos acontecimentos, pretendia sobretudo evidenciar que os portugueses haviam colocado a amarga experiência da "Convenção de Sintra" para trás das costas. Deste modo, Sir Arthur não precisaria de desperdiçar o seu valioso tempo na reconstrução da confiança entre a Grã-Bretanha e os seus aliados, podendo colocar os seus planos em prática com a maior celeridade possível. ${ }^{69}$

Na verdade, poucos dias depois de chegar a Lisboa, Wellesley, com a sua extraordinária capacidade de organização e de comando, conseguira pôr em funcionamento a complexa máquina de guerra necessária para avançar rapidamente rumo ao Norte, resolvendo todos os problemas e as contrariedades que constantemente surgiam no seu bem delineado e programado caminho. Assim, em pouco tempo, Sir Arthur equipara e mobilizara cerca de vinte e cinco mil homens, incluindo mantimentos e transporte - mulas, carros de bois, forragens, carne salgada, aguardente, biscoitos, gado para abate, cartuchos, cobertores e sapatos - supervisionara as tarefas dos

69. V. Scarrow, 2009: 627. 
seus generais e dos oficiais do seu staff, negociara com a Regência, cujos membros não confiavam inteiramente nos britânicos, e preparava-se para marchar até ao Porto, totalmente decidido a expulsar o Marechal Nicolas Soult do país. ${ }^{70}$

Já no rescaldo da retirada de Soult, Wellesley foi ainda muito elogiado pelo narrador de O Mutilado de Ruivães, devido ao facto de ter sido o primeiro a criticar a atitude das tropas britânicas, que roubavam, matavam, exerciam as maiores violências nas casas onde ficavam aboletadas, apoderando-se de diversos animais e utensílios, não obstante o protesto dos seus donos. Em vários momentos, Sir Arthur teria manifestado por escrito um intenso desagrado face ao comportamento indecoroso dos seus homens, tanto junto do Embaixador britânico em Lisboa como junto do Primeiro-ministro em Londres, chegando mesmo "a mandar enforcar alguns soldados pelo cometimento de roubos e outras violências". (Moutinho/Silva, 1980: 165)

Curiosamente, deve notar-se que os narradores de O Segredo do Abade, O Major Napoleão e Os Homens da Cruz Vermelha, numa comparação entre o carácter de Wellesley e de Bonaparte, caracterizam o lorde britânico como um homem de apurado senso comum, inteligente, frio, reflexivo, mas não propriamente genial. ${ }^{71}$ Pelo contrário, nos romances britânicos, a genialidade é uma das características mais frequentemente atribuídas a Sir Arthur Wellesley. Pouco antes do início da travessia do Douro, para a libertação do Porto, Charles O'Malley descrevia a forte impressão que lhe causara a presença daquele homem frio, determinado e genial, que, no momento decisivo, parecia ter nas mãos o destino do mundo:

Never before did I look upon such a perfect impassibility: the cold determined expression was crossed by no show of passion or impatience. All was rigid and motionless, and, whatever might have been the working of the spirit within, certainly no external sign betrayed them; and yet what a moment for him must that have been! Before him, separated by a deep and rapid river, lay the conquering legions of France, led on by one [Soult]

70. V. Youds, 2009: 53-54

71. V. Gama, 1864: 174; Chagas, 1867: 61; e Almeida, 1880, vol. IV: 487. 
second alone to him whose very name had been the 'prestige' of victory. Unprovided with every regular means of transport, in the broad glare of the day (...) he dared the deed. (...)What must have been his reliance upon

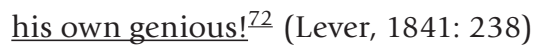

Na verdade, um dos vectores, porventura o mais recorrente que, de alguma forma, atravessam todas as narrativas britânicas prende-se justamente com o elogio, por parte dos narradores e/ou das personagens, à genialidade de Sir Arthur Wellesley, a qual se tornara evidente desde muito cedo. ${ }^{73} \mathrm{Um}$ dos múltiplos exemplos que, neste contexto, se poderia dar, encontra-se associado à eficácia das Linhas de Torres. Assim, tal genialidade assentaria em três vectores fundamentais: a forma como articulara toda a sua estratégia, antes e durante a invasão de André Masséna, em função das Linhas de Torres; o trabalho incansável e metódico a que se dedicava diariamente; e, por fim, a inteligência extraordinária com que soubera manter o secretismo durante os trabalhos de construção das fortificações inexpugnáveis.

O primeiro aspecto foi assinalado, por exemplo, pelo narrador de Lads of the Light Division, o qual acentuava o cariz visionário de um chefe militar verdadeiramente excepcional. Assim, na sua perspectiva, enquanto os franceses se preparavam para o que os seus generais esperavam ser a derrota total das forças aliadas, Wellington, cuja ideia premente era a protecção de Lisboa, tinha preparado as Linhas de Torres para defender a capital e sabia que quando se encontrasse protegido atrás dessas fortificações, poderia desafiar a Europa inteira. Em número muito inferior ao inimigo, o exército aliado teria poucas hipóteses de "virar o jogo" contra os franceses até à chegada de reforços de Inglaterra e, consequentemente, em Setembro de 1810 a estratégia de Wellington visava atrasar o inimigo o máximo tempo possível, com a esperança de o defrontar e vencer, ocasionalmente durante o recuo táctico até Torres Vedras. ${ }^{74}$ A sua extraordinária capacidade de trabalho e de organização, resultantes, em parte, da grande necessidade em cumprir o seu dever e de dar o melhor exemplo aos subordinados, foram assinalados sobretudo em A Different

72. Sublinhado nosso.

73. V. Gilson, 1898: 121.

74. V. Mockler-Ferryman, 1909: 94-95. 
Kind of War, justamente a propósito da planificação e da construção das Linhas. O narrador caracterizava-o como um homem enérgico, metódico e com uma clara noção de como haveria de enfrentar os desafios. Abraçava o seu dever com grande entusiasmo e equilibrava as exigências das suas tarefas militares e diplomáticas com grande mestria. Pela sua secretária passavam diariamente vastas quantidades de papelada, mas Wellington orgulhava-se de nunca se retirar à noite, sem que tudo estivesse tratado e arrumado. ${ }^{75} \mathrm{O}$ último vector enunciado - a inteligência extraordinária com que soubera manter o secretismo das fortificações - tornou-se particularmente visível em Sharpe's Gold, por exemplo, no momento em que o protagonista e o seu companheiro de viagem se aproximavam da primeira Linha de defesa:

They rode in the lengthening shadows down the paved highway into Lisbon. It was crowded with carts, carrying building stone, and with the labourers who were making one of the great wonders of military world, a fortress covering five hundred square miles that would stop the French in the year 1810 and would never be used again. Sharpe admired Wellington for a clever man ${ }^{76}$ because no one outside Lisbon, seemed to know the lines existed, and the French, their tails up, would come hallooing down the southern road. And stop. (Cornwell, 1981: 245)

Não obstante o facto de, nos romances britânicos, Wellington ter sido, indiscutivelmente, representado como um génio, um brilhante estratega e um chefe militar cujo comportamento era irrepreensível, por vezes os narradores não deixaram de aludir à oposição que se fazia sentir em Inglaterra face às medidas adoptadas na guerra da Península pelo recém-nomeado Par do reino. Deste modo, de acordo com o narrador de The Snare, em Londres, os jornalistas medíocres e os homens do calibre de lorde Grey ${ }^{77}$ ao criticarem e censurarem de forma precipitada as operações de

\footnotetext{
75. V. Youds 2010: 37.

76. Sublinhado nosso.

77. Tratava-se de Charles Grey (1764-1845), $2^{\circ}$ Conde de Grey, deputado e depois Ministro dos Negócios Estrangeiros e Primeiro-m Ministro no início do reinado de William IV, cargos que ocupou por curtos períodos de tempo. Lord Grey foi partidário de Fox, defendia a reformas eleitoral, tendo-se sempre deparado com a forte oposição dos Tories e da Câmara dos Lordes. Politicamente, Grey seguiu uma linha contrária à de Wellington.
} 
Wellington, só demonstravam a sua enorme ignorância militar. Todavia, Sir Arthur tivera conhecimento da explosão de ira e da denúncia feita pela oposição quando, meses antes, fora feito Par do reino, após a vitória de Talavera, e, portanto, tinha plena consciência da impopularidade crescente da guerra na Grã-Bretanha, bem como da impaciência do Governo perante a sua aparente falta de actividade nos últimos meses. Desconhecendo o que se estava a preparar tão intensamente - as Linhas de Torres - um dos membros do Cabinet ter-lhe-ia escrito, de forma exasperada e gratuita, o seguinte: "For God's sake do something - anything so that blood be split." (Sabatini, 1817: 3) 78 $^{\mathrm{Se}}$, para os seus homens, Wellington era, indiscutivelmente, o único general britânico capaz de derrotar os franceses, os seus compatriotas em Inglaterra, tiveram algumas dúvidas acerca disso. ${ }^{79}$ No entanto, essa oposição serviu, não raro, o mesmo propósito, ou seja, enaltecer (ainda mais) a determinação $\mathrm{e}$ as qualidades de comando deste "duque de ferro". ${ }^{80}$ Considera-se, aliás, que as narrativas em inglês pretenderam veicular a ideia de que teriam sido justamente essas qualidades que haviam permitido ao chefe britânico lidar com todas as dificuldades criadas pelos governantes portugueses, tal como se pode constatar no excerto seguinte, resultante de um diálogo travado entre dois oficiais britânicos, Dick Ryan e Terence O'Connor, personagens ficcionais de Under Wellington's Command:

'The Portuguese government is as troublesome and as truthless as that of Spain, but Wellington is able to hold his own with them, ${ }^{81}$ and there is little doubt that the regular regiments will fight and be really of valuable assistance to us, but these have been raised in spite of the constant opposition of the Junta at Lisbon.' (Henty, 1899: 161)

78. Veja-se também Youds, 2010: 36-37.

79. V. Cornwell, 1981: 29.

80. V. Sabatini, 1917: 3.

81. Sublinhado nosso. 
Em síntese, pode afirmar-se que, de um modo geral, os romances portugueses perpetuaram na memória colectiva do povo uma imagem bastante positiva do "salvador da pátria." 82 Para os britânicos, Wellington era um homem verdadeiramente excepcional, um génio, um grande herói nacional.

\section{2. "The Great Man", "the Boney", "the Corsican Tyrant", "o Anti- Cristo", "o Génio do Mal", "o César Francês" ou "a Grã-Besta do Apocalipse: Napoleão Bonaparte}

Contrariamente a Wellington, Napoleão Bonaparte (1769-1821) surgiu como personagem ficcional apenas num romance português, A Filha do Polaco, e ainda assim a propósito da acção da Legião Portuguesa fora do país. Neste contexto, esse conjunto de homens portugueses ter-lhe-ia merecido particular atenção, mas como estava longe e recebia com inevitável atraso as informações relativas àquelas unidades, ter-se-ia visto na necessidade frequente de modificar ou anular num dia as ordens que dera na véspera. $O$ narrador veiculava ainda a ideia, também explorada a propósito de Nicolas Soult e sobretudo de André Masséna, de que Napoleão contava muito com a bravura dos seus marechais, mas confiava pouco no espírito de cooperação entre eles, pois por inveja, ciúmes, rivalidades ou desejo de benesses por parte do Imperador, os chefes militares franceses tentavam, não raro, projectar o seu brio pessoal em prejuízo de uma estratégia comum e do êxito de uma campanha. Assim, Bonaparte não se limitava a indicar-lhes o objectivo político ou o plano militar, mas tutelava-os enviando com uma periodicidade extraordinária cartas com ordens muito específicas. ${ }^{83}$

De facto, como se sabe, Napoleão nunca pisou o solo português, o que justifica, em grande medida, a sua ausência nas narrativas ficcionais lusas. Não obstante, encontram-se várias referências à personalidade do Imperador, as quais não eram muito abonatórias em relação ao seu carácter. Excêntrico, obstinado e despótico também

82. Cf. Leitão, 1990: 136-138 e/ou Bello, 2003: 71.

83. V. Júnior, 1903, vol. III: 6. 
nas suas relações pessoais e de amizade, Napoleão chegava a ser ingrato e cruel para com aqueles(as) que, não raro por mero capricho de imperador, tinham passado a ser presenças indesejáveis. Assim, de acordo com o narrador de No Tempo dos Franceses, "quem caísse no desagrado de Napoleão não podia viver sossegado no lugar que lhe aprouvesse", (Benevides, 1894: 166) pois Bonaparte facilmente emitia uma ordem de exílio que desterrava qualquer um para locais absolutamente imprevisíveis. ${ }^{84}$

Para os narradores portugueses, o casamento com a jovem princesa austríaca, Marie Louise de Habsburg, coroava, em 1810, a vertiginosa ascensão de Bonaparte, mas representava também o seu sonho louco de grandeza. Para o narrador (e protagonista) de Vencer ou Morrer, o matrimónio simbolizava o cúmulo da ironia na contradição patente entre os ideais da Revolução e o comportamento do Imperador: o chefe da Casa da Áustria, depois de sofrer humilhantes derrotas infligidas por Napoleão, tornava-se não só seu sogro, mas também seu aliado. Por outro lado, Bonaparte, depois de se divorciar da sua Imperatriz crioula, Joséphine, casava, numa cerimónia de grande ostentação, com uma sobrinha-neta da malograda Rainha Marie Antoniette. ${ }^{85}$ Da perspectiva do narrador de O Mutilado de Ruivães tratava-se de uma aliança que "lhe havia de ser fatal, porque fora imposta mais pela força das armas do que pelos ditames da amizade e dos interesses económicos e espirituais prevalecentes entre os dois grandes estados." (Moutinho/Silva, 1980: 271)

O narrador de O Anel Misterioso considerava que Napoleão utilizara sempre a força dos seus exércitos e o sofrimento dos soldados para vencer os opositores e, à medida que ia acentuando o seu poder, o homem que, no passado, tanto pugnara pela liberdade dos povos tinha-se transformado num déspota cada vez mais audacioso, um verdadeiro tirano, um César que tudo e todos subjugava à sua vontade e ao sabor das suas fantasias. ${ }^{86}$

Muitas das referências feitas pelos textos a esta controversa figura histórica consubstanciavam, em grande medida, a imagem paradoxal das grandes personalidades francesas veiculada pelos textos em

\footnotetext{
84. Veja-se também Benevides, 1894: 303-308.

85. V. Henriques, 2010: 249.

86. V. Pimentel, 1873: 186-188,
} 
apreço. Deste modo, atraídos pelos ideais da Revolução e até, numa primeira fase, pelas ideias de Bonaparte, as personagens dos romances portugueses não podiam concordar, de forma alguma, com certas acções do Imperador e muito menos com a invasão do reino pelos seus exércitos. Atente-se, a este propósito, nas palavras de Daniel Pinto, uma das personagens principais de O Amor em Armas:

- Porque - justificava [Daniel] - uma coisa são as ideias políticas e outra a sua prática, sendo inadmissível impô-las pela força das armas a invadir e pilhar os povos. Também é manifesto que a acção de Napoleão, um autocrata que a si próprio pôs a coroa de Imperador, nada tem a ver com o ideário da liberdade, igualdade e fraternidade que deriva da Revolução Francesa. Por isso, como português, que sou acima de tudo e de tal me orgulho, propugno a luta armada contra os invasores (...). (Vidal, 2009: 165)

Apelidado de "Boinaparte", "anticristo" ou "inimigo do Papa de Roma e do Senhor Príncipe Regente", (Gama, 1864: 29) Napoleão era, simultaneamente, reconhecido como um homem excepcional na sua genialidade, "o mais assombroso general que o mundo tem conhecido," um homem verdadeiramente prodigioso, que, "partindo de tão baixo, atingira os píncaros mais vertiginosos das grandezas humanas." (Chagas, 1867: 9 e 25-26) A imagem de grande opressor cruzava-se, assim, com a de figura providencial, que, lutando contra o despotismo, percorria a época com o fulgor e a rapidez de um relâmpago. ${ }^{87}$

Nas narrativas britânicas em apreço, Napoleão surgiu como personagem apenas em Fire and Sword, embora fosse referido em muitas outras, à semelhança, aliás, do que se verificou nos romances em português.

De todas as possibilidades de caracterização de Bonaparte em Fire and Sword, uma das que se afigurou mais curiosa resultou da forma como o próprio Wellesley, também uma das personagens principais da narrativa, percepcionava o seu futuro rival. Para Sir Arthur, Napoleão comungava de um defeito de carácter existente em alguns

87. V. Gama, 1863: 248-249; Silva, 1865: 32-33; Chagas, 1867: 15-17 e 23; Dias, 1902: 136; e Moutinho/ Silva, 1980: 271 . 
homens que os levam a desejar o poder sem limites. Em consequência, nunca se sentem satisfeitos com o serviço que prestam ao seu próprio país, pois o seu sentido de dever é de tal modo corrompido pela ambição que só sentem obrigações para com eles próprios, ignorando tudo o resto. Todavia, Bonaparte era também fruto de um momento específico da História, pois se não fosse a Revolução em França dificilmente teria alcançado qualquer posto significativo no exército. Para Wellesley, a Revolução concebera Bonaparte, da mesma forma que criara muitos dos que então ocupavam cargos de poder em França. A Revolução dera forma a Napoleão, oferecera-lhe todas as oportunidades de progresso na carreira militar e política, conduzira-o ao despotismo, forçando os britânicos a combatê-lo até às últimas consequências. ${ }^{88}$ Deve notar-se que, em muitos momentos, esta apreciação do carácter de Bonaparte constituía, em grande medida, uma forma indirecta de enaltecer a personalidade do futuro Duque de Wellington.

Em Charles O'Malley, Napoleão Bonaparte foi caracterizado como um homem caprichoso, de mau génio e temido pelos seus inferiores. ${ }^{89}$ Em Death to the French e A Different Kind of War foi ridicularizado e criticado devido ao seu recente casamento com Marie Louise, acontecimento também referido nos romances portugueses, como se viu. Assim, tanto nas narrativas em inglês como em português, a ausência de Napoleão na Península, em 1810, foi maliciosamente atribuída à sua distracção com assuntos domésticos e operações conjugais:

'We had expected Napoleon himself,' said General D'Urban (...) a note of disappointment in his voice, 'but it appears he finds himself otherwise engaged.'

'The gentleman has discovered that his new marriage agrees with him, do you think?' William Warre asked a twinkle in his eye.

There were knowing smiles: they were all aware that the emperor had long told the world he was coming to Spain at the head of a mighty army, finally to crush the hated English and evict them the Peninsula, but it seemed he had become distracted by the problems of divorce and then by his showy

88. V. Scarrow, 2009: 482-483.

89. V. Lever, 1841: 263. 
marriage to Marie Louise of Austria. Now it appeared that he had decided that domestic matters in Paris were more important than the business of dealing with the British troublemakers and he had given the honour of completing the task to Marshal Masséna (...).' (Youds, 2010: 53) ${ }^{90}$

Em Death to the French, as personagens francesas, a passarem grandes dificuldades para sobreviver às portas das Linhas, acusavam-no claramente de se pavonear com a sua jovem e recente esposa, ganha pelo direito de conquista - uma autêntica princesa de Habsburgo, descendente de imperadores -, pouco se importando com a situação dos homens que enviara para tão longínquas e inóspitas paragens. ${ }^{91}$

Por seu turno, os soldados ao seu serviço sentiam-se traídos por promessas não cumpridas e mostravam-se muito desapontados face à ausência do Imperador nesta nova campanha, pois sabiam que o comando de Bonaparte era sinónimo de glória para os seus homens. Embora reconhecessem que Napoleão saberia, decerto muito bem, o que estava a fazer, as causas mais evidentes dessa ausência pareciam-lhes pouco aceitáveis. Assim, de acordo com o narrador de A Different Kind of War, os homens estavam insatisfeitos, sentindo que a verdadeira glória lhes estava a ser negada porque iam ser enviados para uma "terra de trevas" sem o seu grande cabo-de-guerra. Contrariamente a tudo o que lhes tinha sido prometido e a todas as notícias dos jornais, informando que o Imperador ia cair sobre o inimigo e atirar os leopardos ao mar, agora parecia que Bonaparte não viria em pessoa chefiar o exército. Fora uma amarga surpresa para todos aqueles que tinham marchado desde Bayonne ou de mais longe ainda. Todos sabiam que onde estava o Imperador, onde Napoleão comandava, havia glória garantida. Bonaparte sempre dissera que desejava chefiá-los em pessoa, que queria lá estar quando os ingleses fossem expulsos e os impertinentes portugueses e espanhóis postos no seu lugar. Porém, tinha-se tornado evidente que o Imperador iria abdicar dessa satisfação. Estava demasiado ocupado em Paris, a celebrar o seu novo e importante casamento e a forjar habilmente as

90. Veja-se também Henriques, 2010: 250.

91. V. Forester, 1932: 46. 
relações diplomáticas que poderiam manter os austríacos, os russos e os prussianos controlados enquanto ele tratava da Península. Os soldados sentiam-se terrivelmente desiludidos, mas reconheciam que o Imperador sabia certamente qual o melhor caminho a seguir. ${ }^{92}$

Tanto em Sharpe's Gold como em Sharpe's Escape, Napoleão foi caracterizado de forma muito idêntica à dos chefes militares franceses que surgiram como personagens em outras narrativas da autoria de Bernard Cornwell, como Soult e Masséna. Assim, no primeiro caso, a mil milhas de distância da fortaleza de Almeida, Napoleão, "a small man with un untidy hank of hair and an insatiable appetite for work", (Cornwell, 1981: 118) mostrava-se pouco satisfeito com o que lera no último despacho enviado por Masséna e interrogava-se se o Marechal, que ele próprio convertera em Príncipe de Essling, estaria a perder faculdades, pois não compreendia por que razão demorava tanto tempo a atingir os seus objectivos, nomeadamente o de entrar em Portugal. Porém, confiando excessivamente nas capacidades dos seus exércitos e acreditando que mais tarde ou mais cedo os britânicos apenas teriam pela frente o terror, a vergonha e a derrota, Napoleão bocejou e foi-se deitar com a sua princesa austríaca. Enquanto isso, o próprio Masséna, também demasiado confiante na vitória, entretinha-se com a sua jovem amante, não muito longe da fronteira portuguesa.

Em Sharpe's Escape, o diálogo travado entre Masséna e o seu staff, reunidos na sala de jantar do palácio do arcebispo de Coimbra, depois da derrota do Buçaco, afigurava-se revelador de um certo desinteresse, por parte de Napoleão, face à dramática situação de L'Armée $d u$ Portugal, decorrente, em grande medida, do excesso de confiança que depositara nos seus exércitos e respectivos chefes. Assim, de acordo com o narrador, quando André Masséna solicitou o envio de mais homens, o Imperador enviara uma mensagem onde se lia que as forças de que o Príncipe de Essling dispunha eram as adequadas, pois o número de tropas inimigas era irrisório e a missão de invadir e conquistar Portugal apresentava-se como uma tarefa fácil. Através do raciocínio do próprio Masséna, o narrador veiculava a imagem de que o Imperador desconhecia totalmente a situação que os seus

92. V. Youds, 2010: 66. 
homens enfrentavam. ${ }^{93}$

Pelo contrário, num diálogo travado entre duas das personagens de With Moore at Corunna tornava-se evidente, para os militares britânicos, que se Bonaparte viesse, em pessoa, chefiar os seus exércitos na Península, o rumo da guerra seria completamente diferente. Das suas perspectivas, a única razão pela qual a Península Ibérica ainda não tinha sido conquistada residia no facto de os generais franceses andarem sempre a discutir entre si, mas com o próprio Napoleão a comandar, a história teria sido ou viria a ser completamente diferente. ${ }^{94}$

Curiosamente, em Too Few for Drums, a astuta e experiente vivandeira, Gwyneth, reconhecia que Napoleão tinha conseguido levar o progresso aos territórios conquistados, melhores condições de vida para os mais desfavorecidos e, talvez mais importante do que isso, tinha conseguido, pelo menos no seio do exército francês, abolir as diferenças de berço, algo que, infelizmente, da sua perspectiva, não acontecia no britânico. Para esta mulher, que tinha aprendido tudo o que sabia nas Guerras Napoleónicas, Bonaparte ainda simbolizava os ideais da Revolução Francesa, a qual mudara para sempre os preconceitos sociais, algo que, lamentavelmente, não previa que pudesses vir a acontecer na conservadora Grã-Bretanha:

'He [Bonaparte] offers roads, bridges, good harvests, a thriving trade, manufactories, aye, and something more, I think, judging from what I have heard from French prisoners in Lisbon. He gives them something no other ruler ever gave them, a share in his glory. In our army is very different Mr Graham.'(...)

'The French are all one, you understand, the rich and the poor, the officers and the rankers. There is no flogging in the French army and the provosts do not hang a man for looting. (...) They made a revolution in France and it will never be the same for them. Perhaps one day we shall make a revolution but I think not. We sing that we are never slaves but it is not really so because in England property is everything and a man is judged not on what he is but on what he owns. (...')(Delderfield, 1964: 138-139)

93. V. Cornwell, 2003: 231-232.

94. V. Henty, 1897: 97. 
Pelo contrário, para um dos protagonistas de Alone With Glory, o Tenente Tom Herryck, Napoleão representava o despotismo, a crença na superioridade da França, a maior ameaça para a Europa e o mais temível inimigo de Inglaterra. Considerando as fronteiras naturais da França idênticas às do antigo Império Romano, Napoleão fizera com que os franceses acreditassem que o seu destino (e até o seu direito) era o de governar a Europa inteira e, portanto, daria todos os passos necessários para alcançar esse fim. ${ }^{95}$ Considerando-o também um tirano atroz, o protagonista de The Spy, não deixava, no entanto, de se surpreender pela forma como aquele homem - decerto extraordinário e porventura com poderes sobrenaturais - conseguia, mesmo sem estar presente, inspirar os seus homens, fazendo-os lutar, até à morte, pela glória do seu nome. ${ }^{96}$

De certa forma, pode concluir-se que, embora por razões diferentes, tanto os romances portugueses como os britânicos veicularam imagens algo paradoxais de Napoleão Bonaparte, mas cujas razões implícitas são fáceis de compreender. Para os ingleses, Napoleão era o déspota a abater, mas era também um homem genial que só poderia ser derrotado por um outro génio. Para os portugueses, Napoleão simbolizava a imagem (aparentemente) paradoxal dos franceses, assente no facto de estes representarem, a um tempo, o invasor impiedoso e violento, mas também o povo oriundo de uma civilização à época considerada modelar e superior.

\section{Nos Filmes}

Através da simplificação e da necessária caracterização visual que a imagem fílmica pede (já que dar corpo implica a opção por dados específicos e concretos, e exige, pela natureza do próprio acto de recepção fílmica, a redução da acção aos seus vectores fundamentais) é mais fácil verificar no cinema, e em alguns filmes televisivos, aquilo que pode deduzir-se da leitura atenta dos romances sobre os quais incidiu o ponto anterior. Wellington e Napoleão são duas figuras que,

95. V. Youds, 2008: 82 .

96. V. Gilson, 1898: 123. 
do ponto de vista da representação histórica e ficcional e do imaginário colectivo europeu, não existem uma sem a outra, funcionando como as duas faces de uma mesma moeda, a de uma Europa em ebulição no início do século XIX, cujo território global se anexava, aos poucos, ao império francês liderado por Bonaparte.

Os destinos destes dois grandes chefes parecem, aliás, estar marcados por sinais que os ligam desde o início: nasceram ambos em 1769, eram ambos ilhéus - Napoleão da Córsega e Wellesley da Irlanda -, procediam ambos de estratos sociais nobiliárquicos, embora a fidalguia de Napoleão começasse por ser mais pobre e discreta do que a do seu congénere britânico, e estudaram contemporaneamente em grandes academias militares, locais que revelaram os seus respectivos talentos, não evidenciados claramente nos estudos anteriores. Napoleão era, porém, desde cedo, um leitor voraz, aliando a capacidade e a curiosidade intelectuais à habilidade estratégica e militar.

À medida que os acontecimentos bélicos do início do século XIX os vieram a opor, tornou-se claro que glorificar um destes dois grandes chefes militares resultava, implicitamente, na valorização (positiva ou negativa) do seu adversário, já que só a grandeza de um deles podia justificar o valor do que se lhe opunha. Tornou-se significativo, por isso, notar que os poemas encomiásticos de Wellington, escritos em Portugal na época da Guerra Peninsular, faziam do Imperador francês o negativo do seu homólogo britânico: Wellington era tanto mais "divino" quanto mais Napoleão se afigurava "diabólico". Tais poemas - vale a pena lembrar - foram escritos em pleno conflito, quando o sofrimento dos portugueses estava no auge e, por outro lado, resultavam de uma absoluta necessidade política, já que era decisivo para o sucesso político-militar da guerra que o povo português não apenas odiasse visceralmente o causador último do seu infortúnio como também apoiasse incondicionalmente o chefe do exército anglo-luso. Estes textos, muitas vezes de discutível qualidade literária, constituem, portanto, uma importante documentação de uma certa forma de radicalização que atingiu a imagética referente a cada um dos dois militares, tipificando as suas características de forma linear e redutora. ${ }^{97}$

97. Cf. Bello, 2007: 71-79. 
Porém, no cinema, realizado muitos anos depois e muitas vezes com a colaboração de actores britânicos, essa espécie de equilíbrio de forças entre os dois colossos militares assumiu uma forma idêntica à dos romances: embora, aqui e ali, se encontrem críticas ou até mesmo retratos caricaturais de um dos dois chefes, a tendência geral foi bastante equilibrada na sua caracterização, denotando a mútua admiração que, para lá da inimizade da guerra, se fazia sentir.

Da cerca de uma dezena de filmes estrangeiros estreados em Portugal sobre a Guerra Peninsular só menos de metade retrataram os seus chefes militares. Para exemplificar atente-se em três casos: o conhecido filme de 1970 dirigido por Sergei Bondarchuk e produzido por Dino de Laurentiis, intitulado Waterloo (sobre a famosa batalha), com Rod Steiger, Christopher Plummer e Orson Welles como protagonistas; a série Sharpe, de que alguns episódios passaram na televisão portuguesa (e que agora, depois dos estudos anteriormente levados a cabo enquanto registo da guerra, se abordam para colher dados mais específicos sobre o retrato de Wellington), e o recente telefilme Napoleon, an Epic Life, de 2002, ou Napoléon Bonaparte, no título original, realizado por Yves Simenon mas falado em inglês, onde brilham as actuações de Isabella Rossellini, John Malkovitch e Gérard Depardieu, ao lado do protagonista, desempenhado por Christian Clavier.

No primeiro (de Bondarchuk) destacam-se duas cenas, que servem para ilustrar a relação de forças entre Napoleão e Wellington e as respectivas personalidades.

Na primeira assiste-se ao início da queda de Napoleão, o momento em que é avisado pelos seus generais de que as tropas inimigas da Áustria, Bélgica, Prússia e Rússia se encontram às portas de Paris, e de que não há outra solução senão abdicar. O realizador foi bem sucedido no seu propósito de dar a ver o drama pessoal e político de um génio ditatorial como Napoleão, que sabia ter o apoio do povo - "France will follow me to the stars if I give her another victory" $^{\prime \prime}$ e acreditava ter o domínio sobre tudo, pelo que tentou, para lá do limite do razoável, negar as evidências e resistir a aceitar o que naquele momento se tornava inevitável. No seu exasperado monólogo ressoa algo dessa espécie de cega e louca teimosia "à Adolf Hitler", quando já nada mais há a defender senão uma força de vontade e uma determinação pessoal que, na iminência da tragédia (a 
batalha de Waterloo) se tornavam patéticas. A certo ponto refere-se o nome de Wellington, e torna-se significativo notar que Napoleão não o receia, embora note que a França o teme, sobretudo por causa da vitória que obteve na Península Ibérica. Depois deste episódio verificou-se o exílio de Napoleão na ilha de Elba e a sua fuga, dez meses mais tarde, aparentemente coroada de êxito, já que as tropas do Rei, chefiadas pelo Marechal Ney, não dispararam sobre ele, e o povo aclamou-o entusiasticamente. O filme de Bondarchuk faz uma abordagem dramática e psicológica aos dois protagonistas, com particular incidência em Napoleão, e apoia-se em excelentes diálogos, recuperando algumas das frases míticas que terão sido proferidas pelo Imperador dos franceses. São exemplos: "Eu sou a França e a França sou eu"; "Não usurpei a Coroa, encontrei-a na sarjeta e apanhei-a com a minha espada. E foi o povo que a colocou na minha cabeça. Quem salva uma nação não viola nenhuma lei"; ou, quando, instado para assinar um tratado de paz, afirmou: "Discutirei a paz sobre o cadáver de Wellington; é essa a minha mesa da paz" ("that's my peace table").

A outra cena deste filme aqui seleccionada retrata Wellington durante um baile na Bélgica. Bondarchuk desenhou-o como muito autoconfiante, corajoso, sem qualquer medo de Napoleão e francamente snob, acusando o herói francês de não ser um verdadeiro gentleman. No caso deste filme, Napoleão saiu favorecido do confronto, pois Wellington demonstrou falta de fé nas suas tropas, sendo posta na boca da própria mulher de Arthur Wellesley a explicitação da admiração que ele próprio teria pelo seu rival francês.

No segundo filme a que nos referimos, o episódio "Sharpe's Eagle" do telefilme Sharpe, verificou-se que a tendência geral, não apenas na representação dos chefes, mas na imagem geral acerca da guerra, ia no sentido de uma maior tipificação, visível, por exemplo, num certo tom jocoso e irónico, que se encontra ao longo de toda a obra. Não se pode esquecer de que se trata de uma longa série televisiva (de 1993 a 2006), com grande sucesso na Grã-Bretanha e que envolveu, portanto, importantes interesses comerciais, os quais pouco se preocuparam com os rigores da verdade histórica. O realizador destes filmes tornou também claro, por diversas vezes, que usava os romances de Tom Clegg apenas como inspiração, criando depois as histórias ao seu próprio gosto. Desta forma, os filmes da série Sharpe contribuíram largamente 
para a difusão de uma certa ideia acerca desta guerra, nomeadamente a de que decorreu sobretudo em Espanha, jogando com a receita fácil do sentimento classicista que vê em Richard Sharpe, militar que vem "de baixo" ("from the ranks"), a figura cheia de mérito mas sempre injustiçada pelas classes mais favorecidas da Grã-Bretanha, formadas por gente snob, mesquinha e invejosa. Em dada cena, retirada de Sharpe's Eagle, que estreou em Portugal com o título A Guerrilha de Sharpe pode ver-se um Lord Wellington algo sarcástico, representado por David Troughton (que seria mais tarde substituído por Hugh Fraser, devido a doença do primeiro), que se queixa da má qualidade das tropas que tem, que depende totalmente do seu aide-de-camps, o Major Hogan, mais culto do que ele, e que é quem no fundo conduz as jogadas políticas e tácticas, por vezes de nível duvidoso, de que Wellesley necessita. Não se está, portanto, diante de um líder de brilhante grandeza e superioridade moral, mas sim perante um chefe político algo ardiloso cujo desejo de poder se sobrepõe por vezes aos interesses mais globais da guerra ou das tropas que conduz.

No terceiro caso, o filme de Simenon sobre Napoleão (um produto internacional e multicultural), encontra-se também o uso de alguns estereótipos e lugares-comuns, que tornam a narrativa mais facilmente aceite e compreensível pelo público. Numa cena relativamente inicial, assiste-se a um almoço sumptuoso partilhado por Napoleão, pelo Rei de Espanha e o filho deste, que concertam entre eles a invasão de Portugal. Se, este diálogo, não passa a melhor das imagens de Portugal, no caso de Espanha o retrato, através do monarca e do seu filho, é francamente caricatural. Na verdade, ambos surgem como seres desprezíveis, apenas preocupados com as suas respectivas ambições - e, por causa delas, rivais um do outro - acabando por ser expulsos da mesa pelo Imperador francês. Pouco depois deste episódio - que, do ponto de vista histórico, tem aspectos certamente discutíveis - Napoleão decide entregar a Coroa de Espanha ao seu irmão José, o qual virá, passado pouco tempo, a fugir de Madrid, quando as tropas francesas se vêem obrigadas a recuar.

Um segundo excerto deste filme tem o interesse de mostrar a capacidade persuasiva de Bonaparte, mesmo relativamente à população. Trata-se do encontro do Imperador com uma camponesa francesa que não o reconhece e que amaldiçoa a guerra e o seu chefe. Nesta cena fica patente não apenas a genialidade carismática de Napoleão, 
mas também a sua teimosa pertinácia, a sua convicção cega de que nunca perderá, mesmo quando todos começam a antever a derrota ("we're never finished").

O filme mostra, pouco depois, como Napoleão virá a perceber mais tarde, após a rendição de Junot, que, ao contrário do que sempre tinha julgado necessário, será conveniente ir até solo espanhol. As imagens que mostram essa sua deslocação revelam um país totalmente devastado, coalhado de mortos e feridos, por entre o arrastar de um exército francês exausto e desmoralizado. Entretanto, na Corte francesa, já se planeia uma conspiração contra Napoleão, com base na certeza de que a campanha na Península foi um fracasso e que o pior poderá estar para vir. Talleyrand, Fouché e Murat são alguns dos que lideram o golpe. Da boca de Talleyrand ouve-se dizer, em dado momento, que a França e a Rússia se encontram em situações opostas, no respeitante aos seus respectivos chefes: os franceses são civilizados, embora Napoleão não o seja, enquanto na Rússia acontece o contrário em relação ao Czar.

O grande erro de Napoleão virá a ser, como se sabe, a invasão da Rússia. O filme ilustra bem este facto, sabendo dar a ver alguns dos traços que caracterizam a imagem de Napoleão enquanto homem algo extravagante, que admira a bravata e gosta de impressionar, mas que mantém uma invulgar capacidade de raciocínio e de análise das situações e dos povos. Ao chegar a Moscovo, sabe avaliar a coragem e a tenacidade do povo que acaba de invadir - tanto que desde logo suspeita do desaparecimento de toda a Corte -, mas afirma não gostar do frio do Kremlin nem do estilo faustoso do quarto do Czar, preferindo dormir na sua tenda improvisada do que na cama excessivamente confortável e luxuosa de Alexandre.

\section{Conclusões}

Contrariamente à caracterização da grande maioria das personagens históricas britânicas, a qual, nas narrativas em apreço, foi quase sempre, algo controversa e até paradoxal, Wellington constitui uma excepção, pois encontra-se acima de qualquer crítica, sendo unanimemente considerado o grande herói da Guerra Peninsular ou o salvador de Portugal do jugo napoleónico. Foram os filmes que 
trouxeram até Portugal uma representação do militar britânico que, sem deixar de o colocar no plano de um herói, arriscaram um tom mais crítico, porventura por olharem com maior distanciamento histórico e até com alguma ironia ideológica para essa figura de membro da nobreza, altivo e superior em relação às classes que comanda. Todavia, ao compararem o carácter de Wellesley com o de Bonaparte, os narradores portugueses tenderam a caracterizar o lorde britânico como um homem de apurado senso comum, inteligente, frio, reflexivo, mas não propriamente genial, ${ }^{98}$ imagem que encontra, de certa forma, o seu paralelo em outras comparações implícitas entre Wellington e os chefes militares franceses, como Soult, por exemplo, ${ }^{99}$ mas sem qualquer correspondência nas narrativas britânicas.

Por seu turno, enquanto nos romances portugueses as imagens (aparentemente) paradoxais de Napoleão, encontram o seu paralelo em representações ambivalentes de figuras francesas da história e da ficção, nas narrativas britânicas, inversamente, foram veiculadas sobretudo imagens estereotipadas e unidimensionais de Bonaparte, idênticas, aliás, às dos grandes chefes militares ao seu serviço: vaidoso, leviano, fútil e demasiado confiante nas suas capacidades. Deste modo, Napoleão (e os seus homens) contrastava em tudo com o seu homólogo britânico, pois Wellington, pelo contrário, era apresentado como um homem frio, responsável e que jamais subestimava o inimigo. Num ponto, porém, portugueses e britânicos pareciam estar de acordo: na ambição desmedida de Napoleão Bonaparte, que, cego pelo seu próprio brilho, visava demasiado alto. Esta foi também a imagem transmitida pelos filmes que estrearam em Portugal, onde se manifestou esse misto de admiração pelo homem superiormente inteligente e carismático que foi Napoleão, por um lado, e da constatação do abismo a que tal ambição e autismo político levaram, por outro. O filme de Simenon chegou mesmo a mostrar esse paradigmático momento da coroação de Bonaparte como imperador, em que, dispensando o papel do Papa como agente desse acto, se coroou a si próprio, num gesto pateticamente megalómano de quem julgava ter a vida e o poder nas próprias mãos.

98. V. Chagas, 1867: 61; e Almeida, 1880, vol. IV: 487.

99. V. Gama, 1864: 174. 
Em síntese, pode concluir-se que as personalidades da História e os factos do passado são sempre percepcionados, (re)interpretados e transmitidos de formas diversas, as quais, por seu turno, se encontram sempre condicionadas por circunstâncias de nacionalidade, de espaço, de oportunidade política ou de momento da escrita. Estas, por seu turno, poderão revelar-se de cariz pessoal, colectivo, político-social, literário ou outros, sendo ainda determináveis pelo(s) horizonte(s) de expectativa dos diferentes públicos leitores, contribuindo, assim, para o perdurar de específicas visões dos acontecimentos históricos, mais ou menos aproximadas da verdade. As representações de Wellington e de Napoleão nas narrativas portuguesas e britânicas, incidindo sobretudo nas características psicológicas e de carácter dos dois chefes - certamente porque tais dados se tornaram essenciais para a construção de personagens credíveis e atractivas -, remetem a dimensão de análise estritamente política e militar para o terreno da historiografia propriamente dita. Na verdade, a tentativa de compreensão do humano, ainda que do ponto de vista ficcional, fornece dados preciosos para a análise histórica. Assim, embora as narrativas literárias e fílmicas possam, por um lado, ter contribuído, até hoje, para a permanência de imagens algo tipificadas e nem sempre rigorosas das personalidades destes dois grandes chefes, tal contribuição não deixa de evidenciar um valor que a própria História pode reconhecer.

\section{Obras Citadas}

\section{I) Fontes Primárias}

\section{Romances}

\subsection{Portugueses}

Almeida, Carlos Pinto de. Os Homens da Cruz Vermelha. Romance Histórico ao Tempo dos Franceses. Lisboa: Tipografia das Horas Românticas, 4 volumes, 1879 (1879-1880).

Benevides, Francisco da Fonseca. No Tempo dos Franceses. Romance Histórico. Lisboa: Tipografia "A Editora", 1908 (1894). 


\section{REAP/JAPS 26}

Chagas, M. [Manuel Joaquim] Pinheiro. O Major Napoleão. Lisboa: Livraria de Campos Júnior Editor, 1872 (1867).

Dantas, Júlio. "O Moleiro de Sula". Marcha Triunfal. Lisboa: Bertrand, 1961 (1954). 193-227.

Dias, Carlos Malheiro. Paixão de Maria do Céu. Lisboa: Livraria Bertrand, 1982 (1902).

Gama, Arnaldo [de Sousa Dantas da]. O Sargento-Mor de Vilar. Episódios da Invasão dos Franceses em 1809. Porto: Livraria Civilização, 1964 (1863).

--- O Segredo do Abade. Porto: Livraria Simões Lopes de Manuel Barreira, 1951 (1864).

Henriques, Mendo Castro. Vencer ou Morrer. Carnaxide: Editora Objectiva/ Suma, 2010.

Júnior, António de Campos. A Filha do Polaco. Romance Histórico. Lisboa: João Romano Torres \& C. ${ }^{\text {a }}$ Editores, 8 volumes, 1945 (1903).

Moutinho, Mário e A. Sousa e Silva. O Mutilado de Ruivães. Romance. (Das Invasões Francesas às Lutas Civis). Braga: Livraria Cruz, 1980.

Pimentel, Alberto [Augusto de Almeida]. O Anel Misterioso. Romance. Lisboa: Livraria Figueirinhas, 1945 (1873).

Silva, Luís Augusto Rebelo da. A Casa dos Fantasmas. Episódio do Tempo dos Franceses. Lisboa: Tipografia da Gazeta de Portugal, 2 volumes, 1865-1866.

Vidal, José Marques. O Amor em Armas. Romance. Alfragide: Oficina do Livro, 2009.

\subsection{Britânicos}

Cornwell, Bernard. Sharpe's Enemy. Richard Sharpe and the Defence of Portugal, Christmas 1812. New York: Harper Collins, 1994 (1984).

--- Sharpe's Escape. Richard Sharpe and the Bussaco Campaign, 1810. New York: Harper Collins, 2004 (2003).

--- Sharpe's Gold. Richard Sharpe and the Destruction of Almeida, August 1810. Harmondsworth: Penguin Books, 1994 (1981).

Delderfield, R.F.. Too Few for Drums. London: Coronet Books, 1992 (1964).

Forester, C.S.. Rifleman Dodd. Charlston, South Carolina: The Nautical \& Aviation Publishing Company of America, 2001 (1932).

Gilson, Charles. The Spy. A Tale of the Peninsular War and the Storming of Badajoz, Founded Upon the Personal Memoirs of Sir Jeffrey Jones, Bart., of Heatherford Hall in Hampshire. London: Oxford University Press, 1936 (1898).

Henty, G.A.. With Moore at the Corunna. A Tale of the Peninsular War. Pennsylvania: Prestonspeed Publications, 2001(1897).

--- The Young Buglers. A Tale of the Peninsular War. London: Latimer House Ltd., 1954 (1880).

Lever, Charles. Charles O'Malley. The Irish Dragoon. London/New York: Routledge, 1841. 


\section{ESTUDOS/ESSAYS}

Mockler-Ferryman, A.F.. Lads of the Light Division. A Tale of the Peninsular War.

London/New York: Thomas and Sons, [1909].

Sabatini, Rafael. The Snare. London: House of Stratus, 2001 (1917).

Scarrow, Simon. Fire and Sword. London: Headline Publishing Group, 2009.

Youds, Peter. Alone With Glory. Bingham: Bicorn Books, 2008.

--- The Colour of Blood. Bingham: Bicorn Books, 2009.

--- A Different Kind of War. Bingham: Bicorn Books, 2010.

\section{Filmes}

Costa, José Fonseca e. Le Blocus, 1990.

Pinto, Joaquim. Para Cá dos Montes, 1993.

Bondarchuk, Sergei. Waterloo, 1970.

Clegg, Tom. Sharpe, 1993-2006.

Kast, Pierre. La Guerrillera, 1981.

Simenon, Yves. Napoleon, an Epic Life (ou Napoléon Bonaparte), 2002.

Simões, Quirino. A Caçada do Malhadeiro, 1967.

\section{II) Fontes Secundárias}

Almeida, Teresa Caillaux de. Memória das Invasões Francesas em Portugal (18071811). Lisboa: Ésquilo, 2010.

Bazin, André. O Que é o Cinema?. Lisboa: Livros Horizonte, 1992.,

Bello, Maria do Rosário Lupi. "Os Bravos Filhos de Albião". Guerra Peninsular. 200 Anos. Lisboa: Biblioteca Nacional de Portugal, 2007. 71-79.

--- "Imagem de Wellington na Guerra Peninsular: a Poesia Encomiástica como Tributo da Literatura à História". Estudos Anglo-Portugueses. Livro de Homenagem a Maria Leonor Machado de Sousa. Ed. Carlos Ceia, Isabel Lousada e Maria João da Rocha Afonso. Lisboa: Edições Colibri/Faculdade de Ciências Sociais e Humanas/Centro de Estudos Anglo-Portugueses, 2003. 59-71.

---, David Evans, Maria de Deus Duarte e Gabriela Gândara Terenas. "Representações da Guerra Peninsular: do Romance ao Ecrã". A Guerra Peninsular: Perspectivas Multidisciplinares. Actas do Congresso Internacional e Interdisciplinar Evocativo da Guerra Peninsular. XVII Colóquio de História Militar nos 200 Anos das Invasões Napoleónicas em Portugal. Coord. Maria Leonor Machado de de Sousa. Casal de Cambra: Caleidoscópio, 2008, vol.II. 149-174.

--- e Gabriela Gândara Terenas. "Da Visão Literária da Guerra à sua Leitura Fílmica: as Invasões Napoleónicas no Cinema em Portugal". ACT 17. Não vi o Livro, mas li o Filme. Org. Mário Jorge Torres. Ribeirão: Edições Húmus, 2008. 125-141. 


\section{REAP/JAPS 26}

Esdaile, Charles. "Sir Arthur Wellesley, Duque de Wellington: uma Breve Biografia". O Porto e as Invasões Francesas 1809-2009. Coord. Valente de Oliveira. Porto: Público - Comunicação Social, SA/Câmara Municipal do Porto, 2009, vol. IV: 75-100.

Leitão, Maria do Rosário Sampaio Soares de Sousa. Wellington na Poesia Portuguesa (Guerra Peninsular). Dissertação de Mestrado. Lisboa: Faculdade de Ciências Sociais e Humanas da Universidade Nova de Lisboa, 1990.

Tarkovsky, Andrei. Le Temps Scellé. Paris : Éditions de L'Étoile/Cahiers du Cinéma, 1989.

Terenas, Gabriela Gândara. Diagnoses Especulares. Imagens da Grã-Bretanha na Imprensa Periódica Portuguesa. Tese de Doutoramento. Lisboa: Faculdade de Ciências Sociais e Humanas, 2004, vol. I. 49-206.

--- Entre a História e a Ficção: as Invasões Francesas em Narrativas Portuguesas e Britânicas. Casal de Cambra: Caleidoscópio, 2012.

--- O Portugal da Guerra Peninsular. A Visão dos Militares Britânicos (1808-1812). Lisboa: Edições Colibri, 2010 (2000).

Ventura, António (Introd.). Linhas de Torres Vedras. Memórias Francesas sobre a III Invasão. Lisboa: Livros Horizonte, 2010.

Vicente, António Pedro. Batalhas da História de Portugal. Guerra Peninsular 18011814. Lisboa: Academia Portuguesa da História/Quidnovi, 2006. 